\title{
Overview of the systematics and diversity of Poales in the Neotropics with emphasis on the Brazilian flora
}

\author{
Marccus Alves ${ }^{1}$, Marcelo Trovó ${ }^{2}$, Rafaela C. Forzza ${ }^{3} \&$ Pedro Viana ${ }^{4}$
}

\begin{abstract}
Poales represents a major part of Angiosperm and Monocot diversity. The families encompass ca. 20,000 species which is about $7 \%$ of the Angiosperms and $33 \%$ of the Monocots. Bromeliaceae, Cyperaceae, Eriocaulaceae, Juncaceae, Mayacaceae, Poaceae, Rapateaceae, Thurniaceae, Typhaceae, and Xyridaceae are the families represented in the Neotropics. In general terms some areas in the Neotropics could be considered hotspots for Poales with a high number of species in several genera and several centers of endemism - the Guayana Shield, Espinhaço Range and Atlantic Forest are highly diverse in Poales. In terms of the Brazilian flora, the order is well represented in the entire country with almost 4,400 species. It represents more than $50 \%$ of the total number of species of Monocotyledons in Brazil. The main goal here is to summarize the available information and provide an overview of the Poales in the Neotropics. The state of knowledge for each family, focused on the Brazilian flora, is provided and reinforces the importance of new studies in key-groups looking beyond the understanding of their diversity on the continent but also the conservation of the species. Key words: Bromeliaceae, Cyperaceae, Eriocaulaceae, Juncaceae, Mayacaceae, Rapateaceae, Thurniaceae, Typhaceae, Xyridaceae.
\end{abstract}

\section{Introduction}

Monocot classification has faced major changes over recent decades, especially as the result of phylogenetic advances (Chase et al. 2000; Dahlgren et al. 1985; Stevens 2001 onwards). Relations among orders have changed while new insights and data on Monocot evolution are continuously updated (Chase 2005; Chase et al. 2006; Davis et al. 2004). After the most recent molecular and morphological data compilations, clades in some groups are more stable (Davis et al. 2004; Chase et al. 2006; Givnish et al. 2010). Clustered within the commelinids clade, Poales is sister to the clade formed by Commelinales + Zingiberales, and now includes 16 families. Among them, Bromeliaceae, Cyperaceae, Eriocaulaceae, Juncaceae, Mayacaceae, Poaceae, Rapateaceae, Thurniaceae, Thyphaceae, and Xyridaceae are represented in the Neotropics. One species of
Restionaceae, Apodasmia chilensis (Gay) B.G. Briggs \& L.A.S. Johnson, is found in South America (in a subtropical area of southern Chile).

The phylogenetic relationships in Poales are moderately to strongly supported (Givnish et al. 2010). However, the high rate of heterogeneity in the order and poor sampling in some genera may cause problems for the interpretation of evolution within this group (Bouchenak-Khelladi et al. 2009, 2104; Givnish et al. 2010).

Poales represents a major part of Angiosperm and Monocot diversity. The families encompass ca. 20,000 species which comprises about $7 \%$ of the Angiosperms and 33\% of the Monocots (Bouchenak-Khelladi et al. 2014; Givnish et al. 2010). Poaceae is the most species-rich family with ca. 11,000 species, while six other families have fewer than 10 species each. Species in Poales are also of outstanding ecological and economic

\footnotetext{
${ }^{1}$ Universidade Federal de Pernambuco, Depto. Botânica, Laboratório de Morfo-Taxonomia Vegetal, 50670-901, Recife, PE, Brazil. Temporary Address: Senckenberg Naturmuseum, Frankfurt am Main, 60325, Germany. alves.marccus@gmail.com

${ }^{2}$ Universidade Federal do Rio de Janeiro, Depto. Botânica, Instituto de Biologia, CCS, Bloco A1, Cidade Universitária, 21941-590, Rio de Janeiro, RJ, Brazil. martrovo@gmail.com

${ }^{3}$ Jardim Botânico do Rio de Janeiro, R. Pacheco Leão, 915, 22460-030, Rio de Janeiro, RJ, Brazil. rafaela@jbrj.gov.br

${ }^{4}$ Museu Paraense Emílio Goeldi, Coordenação de Botânica, Av. Perimetral, 1901, Terra Firme, 66077-830, Belém, PA, Brazil. pedroviana@museu-goeldi.br
} 
significance. Many biomes and open vegetation areas are dominated by grass-like species, such as some of the savanna formations. Several Bromeliaceae species are also of significant ecological importance as epiphytes forming water tanks (Benzing 2000; Bouchenak-Khelladi et al. 2009, 2104; Givnish et al. 2010).

Local economies, as basic resources for several poor communities, use species of Poales in many countries in the Neotropics. The activities are usually associated with exploitation without conservation and management approaches and are often related to production of hand-crafts and also fresh and dried flowers. These intensive procedures can produce high levels of pressure on the conservation of some species (Balslev 1998; Giulietti et al. 1996; Goetghebeuer 1998; Kubitzki 1998; Stützel 1998).

Human evolution and the history of civilization are closely related to agricultural practices in early settlement. Poaceae constitutes the most economically important plant family and the main source of food for humans. Major food sources throughout history including the present, are based mainly on species of the family, such as rice, corn, wheat, barley, oats, rye, and sugarcane, among others, besides other small sources used locally for different proposes and from several species (Judd et al. 2007; Dahlgren et al. 1985). Poaceae also forms extensive grasslands in natural environments worldwide and are the basis of primary productivity in several ecosystems (GPWG 2012).

The circumscription of Poales as comprising 16 families involves several controversies and the phylogenetic affinities among its families are still being debated by the specialists (BouchenakKhelladi et al. 2014; Givnish et al. 2010). Linder \& Rudall (2005) suggested a late Cretaceous origin during the Paleogene with major diversification in the Neogene. The most recent and more comprehensive phylogenies of Poales achieved significant and quite different evolutionary trees. The authors recover the Cyperid, Restid, and Graminid clades and define Bromeliaceae and Typhaceae as belonging to an early diverging branch within the order. However, the consistency of the Xyrid clade is doubtful, and the positions of both Mayacaceae and Xyridaceae are not well established yet. The Cyperid clade, which is not strongly supported by Bouchenak-Khelladi et al. (2014), has been well supported in previous studies
(Michelangeli et al. 2003; Givnish et al. 2010). The phylogenetic positions of Rapateaceae and Typhaceae are also not clear, and their definition may change some concepts of the Cyperid clade and a possible bromeliad clade (BouchenakKhelladi et al. 2014; Givnish et al. 2010). Among the phylogenies available, clades within the Poales have clearly been well supported but often with high variation in their family composition, sampling and methodology used (BouchenakKhelladi et al. 2014; Davis et al. 2004; Givnish et al. 2010).

The information on the systematics and diversity of Neotropical Poales, especially related to the Brazilian species, are roughly divided into large historical reviews, such as Flora Brasiliensis and Das Pflanzenreich, performed by several authors, and recently published advances. In this case, the updated information is available from a variety of sources, such as articles in several scientific journals, books (local and regional floras) and checklists, besides unpublished theses and dissertations.

Our goal is to provide an overview of the knowledge of the Neotropical families of Poales with an emphasis on Brazil. For that purpose, the relevant bibliography related to systematics and diversity was reviewed and summarized here.

\section{Overview}

An overview of the systematics and diversity of Poales is a great challenge even if it is restricted to the Neotropical region and focused on the Brazilian species. The families related to the order are different in several aspects including the availability of updated taxonomic reviews and phylogenies.

The order comprises families considered morphologically very distinct, such as Bromeliaceae, Eriocaulaceae and Rapateaceae. For some of them, Cyperaceae and Poaceae for instance, a set of specialized terminology is almost unique. Additionally, there is a huge difference in number of species (ca. 10,000 spp. in Poaceae versus 2-5 spp. in Mayacaceae and Thurniaceae). Extremes in geographic distribution are also found among the families. Cyperaceae, Eriocaulaceae, Juncaceae, Poaceae, Typhaceae and Xyridaceae are examples of families with world-wide occurrence; distinctly different from Bromeliaceae, Mayacaceae and Rapateaceae, which are mostly restricted to the American continent (one species of each family 
grows in West Africa), and Thurniaceae (not considering the genus Prionium), which is a narrowendemic to a small area in northern South America.

The variety of habitats (e.g. aquatic, rupicolous, epiphytic, terricolous), vegetation types (e.g. grasslands, understory of moist forests, rocky outcrops) and location (sea-level to 4,000 m high) support a range of narrow-endemic species and genera to widespread ones, such as some weeds and subspontaneous species mainly found in Cyperaceae, Poaceae and Typhaceae.

Natural hybridization and economic use (agricultural and ornamental varieties) also play a major role in Poales, especially in Bromeliaceae and Poaceae. These conditions are key problems to species delimitation in some genera, list of taxa and conservation, but also to more accurate phylogenies.

These factors have had visible effects on the level of information that has been built and made available today for the families in Poales and the understanding of their evolutionary relationships (infrafamiliar level and below). Phylogenies with different approaches (based on morphological and/ or molecular markers) have been published for the families but each of them addresses a unique set of morphological and systematic questions aimed at different genera and groups of species.

In general terms some areas in the Neotropics could be considered hotspots for Poales with a high number of species in several genera and several centers of endemism.

The Guayana Shield is located in the northern part of South America and includes parts of Colombia, Venezuela, Guyana, Suriname, French Guyana, and northern Brazil, especially the northern part of the states of Roraima, Amazonas, Pará, and Amapá (Gibbs \& Barron 1993 apud Huber 1995). It is mainly covered by open vegetation (savanna-like) with flat mountains (Tepuis) and humid forest. The rocky outcrops, geographic isolation and climatic conditions are peculiar and play a major role in the diversity and endemism found for Bromeliaceae, Cyperaceae, Eriocaulaceae, Rapateaceae and Xyridaceae in the region.

The Espinhaço Range goes from the states of Bahia (Senhor do Bonfim) to Minas Gerais (Ouro Branco), Brazil and is a group of mountains with latitudinal orientation and altitudinal ranges from 800 to $1,500-1,800 \mathrm{~m}$. It is surrounded by Cerrado (southwestern and southern sides), Caatinga vegetation (northwestern and northern sides) and dry forest as part of the Atlantic Forest Domain (eastern side). Rocky outcrops, locally called Campos Rupestres predominate in the area (Fiaschi \& Pirani 2009; Giulietti \& Pirani 1988) and are highly rich in species of Bromeliaceae, Cyperaceae. Eriocaulaceae, Poaceae and Xyridaceae. Disjunct areas of Campos Rupestres can be found in the state of Goiás (e.g. Chapada dos Veadeiros) as well as in Minas Gerais (e.g. Serra da Canastra, Carrancas, Tiradentes and Ibitipoca, among others).

The Atlantic Forest goes from the drier northern part (states of Ceará as fragmented areas and Rio Grande do Norte) to more humid areas in southern Brazil (state of Rio Grande do Sul) and northeastern Argentina and eastern Paraguay (Fiaschi \& Pirani 2009; Ribeiro et al. 2009; Thomas $\&$ Barbosa 2008). The most humid and diverse section goes from southern Bahia to São Paulo, where high-altitude (up to 3,000 m) grasslands with exposed rocks (locally called Campos de Altitude or Brazilian Páramos by Safford 1999) are common and house many species with several centers of endemism for Bromeliaceae, Cyperaceae and Poaceae.

The Andes Mountains can also be considered a hotspot with several cases of endemism in groups of Bromeliaceae, Cyperaceae, Juncaceae and Poaceae. It is a system of high-altitude mountains which goes from southern Chile and Argentina to Colombia and Venezuela with a south-north orientation and distinct vegetation types and physiognomies from the northern to the southern part, including the Páramos and Punas, which are mostly around 3,000 m altitude, as well as montane forests (Luteyn \& Churchill 2000).

Other areas are also important for some taxonomic groups. The lowland Amazon Forest, for instance, occupies a large part of South America - Trinidad and Tobago, French Guiana, Suriname, Guyana, Venezuela, Colombia, Peru, Ecuador, and Bolivia (Daly \& Mitchell 2000; Fiaschi \& Pirani 2009). It is particularly rich in some groups of Cyperaceae, Poaceae and Rapateaceae. Finally, the Pampas, comprising grassland vegetation with dispersed rocky outcrops and flooded areas is limited to a small geographic area in the subtropical part of South America, including southern Brazil, Uruguay and northeastern Argentina (Fiaschi \& Pirani 2009; Veloso et al. 1991). This area includes many species of Bromeliaceae, Cyperaceae, Juncaceae and Poaceae. 
In terms of the Brazilian flora, Poales is well represented in the country with almost 4,400 species. It represents more than $50 \%$ of the total number of species $($ ca. 8,400) of Monocots cited by LEFB (2014). Four of the five most species-rich families of Monocots (excluding Orchidaceae) in Brazil are members of Poales: Poaceae (1,485 spp.), Bromeliaceae (1,341 spp.), Cyperaceae (673 spp.), and Eriocaulaceae (624 spp.). Almost 1,500 species of Poales are endemic to the country, including ca. $80 \%$ of the total number of species cited to Bromeliaceae, Eriocaulaceae, and Xyridaceae and $30 \%$ of Cyperaceae and Poaceae. Among the 322 genera of Poales confirmed in Brazil, 32 are considered endemic and belong, for the most part, to Bromeliaceae (ca. $40 \%$ of the number of genera of the family are endemic) and Poaceae.

The main goal here is to summarize the available information and provide an overview of the order in the Neotropics. Furthermore, this paper provides the state of knowledge for each family focused on the Brazilian flora and reinforces the importance of new studies in key-groups, aiming beyond the understanding of their diversity on the continent but also the conservation of the species.

\section{Bromeliaceae}

The Bromeliaceae is one of the largest families of flowering plants essentially Neotropical. It is a prominent example of adaptive radiation and one of the most diversified Monocots with respect to habit, ecological range, and habitat (Benzing 2000; Smith \& Downs 1974). Three centers of diversity can be recognized for the bromeliads: the Atlantic Forest in eastern Brazil, the Guayana Shield and the Andes (Martinelli et al. 2008; Smith \& Downs 1974).

Comprising 58 genera and ca. 3,400 species (Luther 2012), Bromeliaceae is one of the typical elements of Neotropical forests (Benzing 2000). Givnish et al. (2007) demonstrates that modern lineages of bromeliads started to diverge around 19 million years ago. The origin of the group was traced back to the Guayana Shield in northern South America and from there spread throughout the Neotropics. Pitcairnia feliciana (A. Chev.) Harms \& Mildbraed is the only species outside the continent and reached western Africa through relatively recent long-distance dispersal, around 10 million years ago (Givnish et al. 2007).

Brazilian bromeliads are outstanding in their diversity and endemism, with 43 genera and 1,341 species, of which 1,172 are endemic to the country. The Atlantic Forest is a well-known center of diversity for the family and holds ca. 900 species. A secondary center is the Campos Rupestres with almost 200 species, most of which are endemic (Forzza et al. 2014). Bromeliads are also highlighted by their unfortunate situation in terms of conservation, being the second plant group in absolute number of threatened species in the country (202 spp.), behind Asteraceae, which is in fact the largest flowering plant family in Brazil (Martinelli et al. 2013). The overall population size is often small, with restricted distributions and highly specific habitats. Such attributes, combined with accelerated habitat loss, degradation of remaining native vegetation and exploitative practices have pushed many species close to extinction, mainly in the Atlantic Forest (Forzza et al. 2013).

While the delimitation of the family does not seem to raise any controversy, the circumscription of infra-familiar categories continues to be widely questioned and changed over time. Pitcairnioideae, Tillandsioideae and Bromelioideae (Smith \& Downs 1974) have shown to be artificial under a phylogenetic approach (Gilmartin \& Brown 1987; Horres et al. 2000; Terry et al. 1997). In order to clarify the relationships within the family, Givnish et al. $(2004,2007)$ widened the number of terminal taxa in the analysis. Following this approach, Bromelioideae and Tillandsioideae were confirmed as monophyletic in contrast with the already suspected polyphyletic Pitcairnioideae. Givnish et al. (2007) proposed each clade of Pitcairnioideae as distinct subfamilies, increasing to eight the total number.

However, the progress in understanding bromeliad evolution at the higher levels is not reflected at the generic and species levels. Most phylogenetic studies, even with large sets of molecular markers, have demonstrated that the generic circumscription is far from being wellsupported (e.g. Almeida et al. 2008; Barfuss et al. 2005; Faria et al. 2004; Givnish et al. 2011; Gomes-da-Silva et al. 2012; Louzada et al. 2014; Sass \& Specht 2010; Schulte et al. 2009; Versieux et al. 2012). The low variability of the molecular markers (Krapp et al. 2014) might be overcome by combining the data set with morphological characters, a possibly good alternative as stressed by some authors (Almeida et al. 2008; Costa et al. 2014; Gomes-da-Silva 2009; Horres et al. 2007; 
Mantovani et al. 2012; Monteiro 2009; Monteiro et al. 2010; Santos-Silva et al. 2013; Saraiva 2013; Sousa et al. 2007; Venda 2012). Such an approach may offer valuable input regarding the evolution of the family despite being affected by high rates of homoplasy.

Regardless of the difficulty in recognizing monophyletic genera (e.g. Escobedo-Sarti et al. 2013), remarkable progress has been made in the last two decades in terms of taxonomic revisions and local floras. Since the major works by Mez $(1894,1896)$ and Smith and Downs $(1974,1977,1979)$, knowledge of the Brazilian species has been greatly increased.

Recent revisions of exclusively Brazilian genera of Bromelioideae have been carried out: Canistrum, Canistropsis, Cryptanthus, Edmundoa, Eduandrea, Nidularium, Lymania, Portea, Lapanthus, Orthophytum and Wittrockia (Coffani-Nunes 2004; Leme 1997, 1998, 2000, Louzada 2012; Louzada \& Versieux 2010; Louzada \& Wanderley 2010; Ramirez 1996, 2000; Sousa \& Wendt 2008). Species-groups within Aechmea have also been revised (Abondanza 2012; Faria et al. 2010; Siqueira Filho \& Leme 2006; Sousa 2004). For Tillandsioideae, Alcantarea is the only genus that has been fully revised (Versieux 2009), however several studies of species-groups within Vriesea and Tillandsia have been carried out (e.g. Costa et al. 2009; Gomes-da-Silva \& Costa 2011; Moura 2011; Moura \& Costa 2014; Silva 2014; Sousa 2012; Tardivo 2002; Uribbe 2014). For Pitcairnioideae, revisions of Encholirium, Deuterocohnia and Fosterella (Forzza 2005; Peters 2009; Peters et al. 2008; Schütz 2011) have been published, however, the most diverse genera, Pitcairnia and Dyckia, are still limited to floristic studies and descriptions of new species (e.g. Buneker et al. 2013; Esteves \& Gouda 2014; Leme et al. 2010; Martinelli \& Forzza 2006; Saraiva \& Forzza 2012; Wanderley et al. 2014).

Most of the published local floras are from areas in southeastern and southern Brazil, mainly from Campos Rupestres and the Atlantic Forest region (e.g. Barros \& Costa 2008; Coffani-Nunes et al. 2010; Coser et al. 2010; Costa \& Wendt 2007; Forzza \& Wanderely 1998; Guarçoni et al. 2010; Luiz-Santos \& Wanderley 2012; Machado 2012; Monteiro \& Forzza 2008; Moura et al. 2007; Siqueira Filho \& Leme 2006; Versieux et al. 2008, 2010; Versieux \& Wendt 2007; Wanderley \& Forzza 2003; Wanderely $\&$ Martins 2007). There is a clear lack of this kind of information from the central and northern parts of the country.
Several taxa still present a challenge because they are often poorly delimited and seldom represented in herbarium collections. This makes a better understanding of their morphological variation harder. Aechmea, Neoregelia, Cryptanthus, Hohenbergia, Billbergia, Vriesea and Dyckia are examples of the challenges ahead. Endemic genera from the Guayana Shield (Venezuela, Guyana, Suriname, French Guiana, and northern Brazil), which are poorly known and very seldom collected, also deserve more attention.

Species delimitation should include different approaches, such as morphology, genetics, and also reproductive and ecological studies which are relevant for conservation. Recently, studies combing new tools with taxonomic studies have increased information on the complexity of the evolutionary processes involved in bromeliads (e.g. Barbará et al. 2007, 2009; Hmeljeski et al. 2014; Lavor et al. 2014; Louzada et al. 2014; Palma-Silva et al. 2011; Schulte et al. 2010; Versieux et al. 2012; Zanella et al. 2011). In order to support a better understanding of the phenotypic plasticity in the family, continuous improvement in collections and their availability for researchers is mandatory. Finally, studies focusing on speciescomplexes are crucial to fully comprehend the microevolution and to find informative molecular markers for lower hierarchic levels which are probably the new paths for taxonomic studies.

\section{Cyperaceae}

The Cyperaceae is a more or less cosmopolitan family with South America as one of its major centers of diversity (Goetghebeur 1998; Govaerts et al. 2007). Most recent checklists include around 5,300-5,500 species in 100-110 genera, which puts it as the $3^{\text {rd }}$ largest family in the Monocots and $7^{\text {th }}$ among the angiosperms (Alves et al. 2009, 2014; Govaerts et al. 2007; Guaglianone et al. 2008). Carex and Cyperus are the most diverse genera. Carex comprises ca. 2,000 species, mostly from subtropical and temperate zones in the Northern Hemisphere and less well represented in the Neotropics while Cyperus s.l. has ca. 1,000 species and is a cosmopolitan genus with numerous species associated with flooded areas and many others considered weeds. The Neotropical region supports ca. 1,500-2,000 species based on several non-integrated checklists (Adams 1994; Alves et al. 2009, 2014; Camelbecke et al. 2007, Govaerts et al. 2007; Guaglianone et al. 2008; Kearns et al. 1998; Strong \& Acevedo-Rodriguez 2005, 2012), and Brazil accounts for almost 700 of these (Alves et al. 2014). 
Cyperaceae is nested with Juncaceae in recent phylogenies (Bouchenak-Khelladi et al. 2014) in a clade with well-known morphological support. The first one has two accepted subfamilies: Mapanioideae and Cyperoideae, each one with several tribes and subtribes (Goetghebeur 1998; Muasya et al. 2009a; Simpson 1995b) Current research aims to better understand and organize the family classification. Carex is monophyletic, however Cyperus s.l. (including Lipocarpha, Kyllinga, Pycreus, Oxycaryum and Remirea among others) and Rhynchospora (with Pleurostachys as a separate genus) are clearly non-monophyletic but widely cited as independent genera in checklists and herbarium collections (Bauters et al. 2014; Larridon et al. 2013, 2014; Muasya et al. 2009b; Reid et al. 2014; Thomas et al. 2009).

Taxonomic reviews and local floras have been intensively produced in recent decades but not at a scale sufficient to understand the full level of diversity in the Neotropics. Bulbostylis, Cyperus s.l., Eleocharis, Hypolytrum, Kyllinga, Machaerina, Mapania, Rhynchospora, and Scleria have been the focus of recent studies but are still far from being fully understood in terms of their diversity and evolutionary relationships.

Several hotspots in the Neotropics can be indicated for Cyperaceae: the Guayana Shield, the Espinhaço Range and the central-southern part of the Atlantic Forest (from Bahia to Santa Catarina, including Minas Gerais). The Andes Mountains can also be considered a hotspot for the family as well as the grasslands (Pampas) in southern South American, but this latter biome mainly supports genera and species of subtropical and temperate zones.

These hotspots account for almost $75 \%$ of the diversity found on the continent and hold very distinct physiognomies and vegetation types, which are often unique in terms of genera and endemic groups.

The Guayana Shield has 413 species of Cyperaceae recorded so far (Camelbecke et al. 2007; Kearns et al. 1998). It also houses small and endemic genera, such as Cephalocarpus (4 spp.), Everardia (11 spp.) and Koyamaea (monospecific). This area is also an important site for subgroups of Cryptangium, Lagenocarpus, and Rhynchospora (Alves et al. 2014; Camelbecke et al. 2007). The Espinhaço Range is a hotspot for several genera including Bulbostylis, Cryptangium, Cyperus, Lagenocarpus, Rhynchospora and Scleria
(Simpson 1995a). The central-southern part of the Atlantic Forest from southern Bahia to São Paulo holds some highly diverse genera. In this narrow stretch of humid and shady forest with several high-altitude and exposed rocky outcrops, ca. 25 endemic species of Hypolytrum, Machaerina, and Pleurostachys can be found (Alves et al. 2014). The most diverse genera in the Andes region are Bulbostylis, Carex, Scirpus and Uncinia (Guaglianone et al. 2008).

Brazil, as the largest country in the tropical part of the South American continent, plays a major role in the diversity of Cyperaceae (Luceño \& Alves 1997; Alves et al. 2014), mainly because of its large variety of biomes, ecosystems and vegetation types.

The available checklists for the Amazon Forest as a whole comprise at least $800-850$ species names including almost 300 from the Brazilian portion (Alves et al. 2014; Camelbecke et al. 2007; Kearns et al. 1998). The forested area has genera typically not found in savanna vegetation, such as Bisboeckelera, Calyptrocarya, Diplacrum, Diplasia, Hypolytrum and Mapania. Several examples of geographic disjunction among genera and species between the Amazon and Atlantic Forest have been recorded (Alves et al. 2003; Alves \& Thomas 2015; Luceño et al. 1999).

Caatinga is a semi-arid vegetation exclusive to northeastern Brazil and a naturally poor habitat for Cyperaceae as well as other families of Poales. However, more than 130 species are cited, most of which are associated with temporary streams, islands of humid forest and rocky outcrops (Alves et al. 2014; Luceño et al. 1999). Cerrado, Chaco and Pantanal are found in southwestern Brazil, Bolivia and Paraguay and are connected ecosystems which share several vegetational similarities including species. It is a very rich area for Cyperaceae especially for Bulbostylis, Cyperus, Eleocharis, Fuirena, Rhynchospora and Scleria related to fire-tolerance and rocky outcrops (common in Cerrado) and floods (Pantanal). Including the species recently cited for Brazil (Alves et al. 2014; Araújo et al. 2009), the diversity of Cyperaceae in the area easily reaches 450 species.

The grassland-like vegetation from the Pampas is highly rich in species of Cyperaceae as pointed out by Guaglianone et al. (2008) and Alves et al. (2014) with ca. 200 recorded taxa. Bulbostylis, Eleocharis and Rhynchospora are among the most species-rich genera. 
Central America (including Mexico) and the Caribbean Islands also comprise a peculiar combination of ecosystems (lowland forest to subalpine vegetation in high altitudes and volcanic areas) and species of Cyperaceae. More than 100 species are considered endemic to the area which supports a total of 450-500 taxa recorded so far (Adams 1994; Goméz-Laurito 2003; Strong \& Acevedo-Rodriguez 2012). The most species-rich genera are Cyperus, Rhynchospora and Scleria.

\section{Eriocaulaceae}

The Eriocaulaceae is a pantropical family consisting of ca. 1,200 species with ca. 850 species and nine genera concentrated in South America, especially in Brazil. The main centers of taxonomic and morphological diversity are the Espinhaço Range and the Guayana Shield, comprising more than $80 \%$ of the species (Giulietti \& Hensold 1990; Giulietti et al. 2000, 2005, 2012; Stützel 1998). Secondary centers of diversity are located in the central savannas, especially in Goiás and Mato Grosso, and in the Amazon Forest domain. In these two areas diversity is greatly underestimated, as they have been poorly collected and barely studied (Giulietti et al. 2005, 2012).

The evolutionary relationships among the genera of Eriocaulaceae have only been partially elucidated. Both subfamilies and most of the genera are monophyletic, except for Paepalanthus (Andrade et al. 2010; Giulietti et al. 2000, 2012; Trovó et. al. 2013). In order to resolve the polyphyly of Paepalanthus, a broad sense of the genus would have to include Actinocephalus, Tonina, and Lachnocaulon. However, more detailed studies are required to justify keeping Paepalanthus in a broad sense or to split it into a few, more robust genera. The systematic position of Syngonanthus, Comanthera and Leiothrix is somewhat unstable and Rondonanthus is still poorly sampled. Published phylogenies within the genera have been restricted to Comanthera, Leiothrix, and P. subg. Xeractis and all of them highlighted the importance of biogeography in the evolution of species of Eriocaulaceae (Echternacht et al. 2011, 2014; Giulietti et. al 1995).

In the Neotropics, Paepalanthus is the most species-rich genus. It comprises 337 species in Brazil, of which 322 are endemic to the country (Giulietti et al. 2005, 2012). Most of the species occur in Minas Gerais (265 spp.) and Bahia (40 spp.) and often on rocky outcrops (Giulietti et al. 2014). As the most morphologically and taxonomically diverse, the genus also encompasses the majority of the taxonomic and nomenclatural issues. After the historical manuscripts (Bongard 1831; Koernicke 1864; Ruhland 1903) and descriptions of hundreds of species and varieties by Álvaro da Silveira and Harold Moldenke, some revisionary studies have addressed ca. $25 \%$ of the valid names. Paepalanthus ser. Paepalanthus $(=P$. ser. variabiles), which contains ca. $60 \%$ of Paepalanthus species, is still poorly studied.

Hensold $(1988,1991,2004)$ revised $P$. subg. Xeractis and $P$. subg. Monosperma. Tissot-Squalli (1997a,b,c) revised P. subg. Platycaulon and Trovó \& Sano (2011a), P. sect. Diphyomene. Trovó and Stützel (2013) transferred $P$. subg. Psilandra to Syngonanthus. Additionally, some isolated nomenclatural changes and species descriptions have been published quite recently (Echternacht $e t$ al. 2012; Trovó \& Sano 2009, 2010a,b, 2011, 2014; Trovó et al. 2011, 2012a, 2013, 2014).

Syngonanthus is also quite a diverse genus, comprising ca. 100 species distributed mainly in South America, but with some African and North American species as well (Giulietti \& Hensold 1990; Giulietti et al. 2005; Stützel 1998). The 95 Brazilian species are distributed all over the country, but concentrated in the Cerrado. It is the most diverse genus of Eriocaulaceae in the Amazon. In addition to new species and nomenclatural updates (Hensold 2004; Hensold et al. 2012; Parra \& Giulietti 1997), a synopsis is about to be published (Echternacht pers. comm.).

Eriocaulon is the largest genus of Eriocaulaceae with ca. 450 species usually associated with humid or aquatic habitats. Its distribution is truly pantropical, with at least one species reaching temperate areas in Europe (Giulietti \& Hensold 1990; Giulietti et al. 2005, 2012; Stützel 1998). However, it is less diverse in South America, with 57 species occurring in Brazil, of which 40 are endemic (Giulietti et al. 2014). Leiothrix is almost exclusive to Brazil with only L. flavescens (Bong.) Ruhland also found in Venezuela. The rocky outcrops of Minas Gerais hold 35 endemic species among its total of 48. $L$. fluitans (Mart.) Ruhland is the only aquatic taxon in the genus (Giulietti et al. 2014). Recent taxonomic information is scarce for Eriocaulon and Leiothrix, except for nomenclatural notes and new species descriptions (Giulietti 1978; Giulietti \& Hensold 1990; Giulietti \& Miranda 2009; Giulietti et al. 1995; Oliveira \& Bove 2011). 
Actinocephalus and Comanthera were fully revised quite recently. Actinocephalus was established from $P$. sect. Actinocephalus (Sano 2004) and amended with $P$. subsect. Aphorocaulon (Costa $\&$ Sano 2013). It comprises 49 species endemic to Brazil and mostly distributed in the Espinhaço Range in Minas Gerais. Comanthera, recircumscribed based on Syngonanthus sect. Eulepis and S. sect. Tysanocephalus, has 34 species with a similar geographic distribution to that of Actinocephalus. However, some species are restricted to the savannas of northern South America and others are endemic to Bahia. New species have also been recently published in both genera (Costa 2006; Echternacht et al. 2011; Trovó \& Costa 2009; Trovó \& Sano 2010b; Trovó et al. 2012b).

Hensold \& Giulietti (1991) transferred $P$. subg. Bostrychophyllum to a recircumscribed Rondonanthus. With six species, three of them restricted to the Tepuis and surroundings, the genus is poorly known because of the scarce herbarium specimens available (Giulietti et al. 2014; Hensold \& Giulietti 1991). Tonina, a monotypic genus ( $T$. fluviatilis Aubl.), is aquatic and occurs in South and Central America. In Brazil, it is mainly found in freshwater streams or lakes of coastal forests from São Paulo to Piauí (Giulietti et al. 2014).

\section{Juncaceae}

Juncaceae is a family of seven genera and ca. 440 species, most of them are limited to temperate or cold regions of the world, while in the tropics members of the family are often found above (800-)-1,500 $\mathrm{m}$ above msl (Balslev \& Zuluaga 2009). They usually grow in alpine meadows and in grasslands and can be weeds in fields and along roads and trails. Most of the species are placed under Juncus and Luzula and less than 60 of them are found in the subtropics of the American continent and in the southern Andes (Alves \& Luz 2014; Balslev 1996, 1998, 2004; Balslev \& Zuluaga 2008; Novara 1996). Distichia, Patosia and Oxychloe comprise a total of 10 species endemic to high-altitude areas in the Andes from Venezuela and Colombia to Argentina and Chile; Marippospermum (3 spp.) occurs in Patagonia (southern Argentina) while Rostkovia (2 spp.) can be found on sub-Antarctic islands, in Patagonia and at high-altitudes (Paramos) in Ecuador and is an interesting example of geographic disjunction (Balslev 1996, 1998; Balslev \& Zuluaga 2008; Novara 1996). Balslev (1996) pointed out how poorly diverse Luzula (8 spp.) is in the Neotropics compared to Juncus (41 spp.).

Several species of Juncus are halophytic while the cushion-forming genera Distichia, Patosia and Oxychloe are adapted to harsh diurnal freezing and thawing in the Andes and sometimes reach the altitudinal limit of vegetation (Balslev 2004; Balslev \& Zuluaga 2008). In Brazil most of the 22 species of Juncus and Luzula cited (Alves $\&$ Luz 2014) are found in the southern region with some of them occurring at high altitude areas such as the Mantiqueira Range, which is located along the border of the states of São Paulo, Rio de Janeiro and Minas Gerais. Both genera are also found in Central America and the Caribbean (total of ca. 10 spp.). They are cited from lowland forests to high altitudes in volcanic areas up to $3,000 \mathrm{~m}$ above msl where bogs with swampy soils and ponds are common (Acevedo-Rodriguez \& Strong 2012; Hammel 2003).

The species are often grass-like herbs with herbaceous culms, linear leaves, and usually manyflowered inflorescences of small, glumaceous flowers, similar to those found in Poaceae and Cyperaceae. However, Juncaceae emerges with Cyperaceae in the same clade which was previously called Cyperales (Bouchenak-Khelladi et al. 2014). Both families share diffuse centromeres as does Thurniaceae (Simpson 1995b; Balslev 1998; Goetghebeur, 1998).

The family has not been formally split into tribes or subfamilies, but three natural groups have been informally recognized (Balslev 2004). Recently, some molecular evidence has suggested replacing Prionium, a monospecific genus endemic to South Africa, with Prioniaceae or moving it to Thurniaceae (Balslev 2004; Bouchenak-Khelladi et al. 2014).

\section{Mayacaceae}

The Mayacaceae is a small and monogeneric family with five aquatic species currently recognized. It is essentially Neotropical with some species reaching temperate zones in the United States and Argentina, while Mayaca baumii Gürke is a disjunct West African species found in Angola (Carvalho 2007; Lourteig 1952; Stevenson 1998). The taxonomy of the family is based on the last full revision provided by Lourteig (1952), with some adjustments provided by Carvalho (2007). The phylogenetic position of the family is controversial. Mayacaceae was previously understood to be 
related to Commelinaceae, but recent phylogenies place the family within the Xyrid clade or even related to the Cyperid clade (Bouchenak-Khelladi et al. 2014; Givnish et al. 2010). Relations within Mayacaceae remain to be established.

The four Brazilian species of Mayacaceae are spread nearly throughout the country, growing in rivers and perennial or temporary lagoons. Species differentiation is quite a hard task, relying on anatomical features of the androecium, presence or absence of inflorescence and corolla color (Carvalho 2007). For a detailed study, see the overview of Brazilian Mayacaceae published within this volume.

\section{Poaceae}

The Poaceae has at least 11,000 species recorded in ca. 700 genera which makes it the fifth largest plant family and the second among the Monocots (a global checklist is available and continuously updated by Soreng et al. 2014). Grasses are distributed throughout all continents and are found in almost all continental environments of the planet (Judd et al. 2007). Festuca, Poa, Stipa, Eragrostis and Paspalum are the most diverse genera (Clayrton et al. 2006). In the Neotropics, more than 4,000 species of grasses in almost 300 genera are known, with Paspalum and Eragrostis being especially diverse (LonghiWagner \& Oliveira 2009).

According to Bouchenak-Khelladi et al. 2014, Poaceae is a sister group of a clade composed of two small families, Ecdeiocoleaceae (Australia, monogeneric and with 3 spp.) and Joinvilleaceae (Pacific zone, monogeneric and 4 spp.), and comprises the graminid clade with Flagellariaceae (Paleotropics, monogeneric and 4 spp.). The most updated infrafamilial classification for the Poaceae proposed by the Grass Phylogeny Working Group accepts 12 subfamilies and a long list of tribes and subtribes (GPWG 2001; 2011). Anomochloideae, Pharoideae, and Puelioideae comprise the basal grass clade; Panicoideae, Aristioideae, Chloridoideae, Micrairoideae, Arundinoideae, and Danthonioideae make up the PAC-MAD clade; and Pooideae, Errhartroideae and Bambusoideae are the subfamilies of the BEP clade (GPWG 2011). All of them occur in the Neotropics, except Puelioideae (endemic to Africa).

The diversity of grasses in the New World is noteworthy. The Catalogue of New World Grasses (Judziewicz et al. 2000; Peterson et al. 2001;
Soreng et al. 2003; Zuloaga et al. 2003) provided a comprehensive update on the knowledge of the family in the region. Although there is still a lot to be clarified about evolutionary relationships, phylogenies have been published supporting new taxonomic circumscriptions toward a more natural family classification. Phylogenies of Panicoideae (Sede et al. 2008, 2009a,b; Chemisquy et al. 2010; Zuloaga et al. 2010; López \& Morrone 2012; Morrone et al. 2012; Acosta et al. 2014), Bambusoideae (Ruiz-Sanchez et al. 2008; Fisher et al. 2009; Ruiz-Sanchez et al. 2011; BPG: Bamboo Phylogeny Group 2012; Tyrrell et al. 2012; Fisher et al. 2014; Oliveira et al. 2014), Chloridoideae (Columbus et al. 2007; Peterson et al. 2010; Peterson et al. 2012; Peterson et al. 2014), Danthonioideae (Barker et al. 2007; Linder et al. 2010), and Pooideae (Schneider et al. 2009; Romaschenko et al. 2010; 2012; Soreng et al. 2010; Cialdella et al. 2014) are particularly noteworthy.

Some relevant recent taxonomic rearrangements at the generic level that include Brazilian taxa are cited below.

In Panicoideae, Trichanthecium (Zuloaga et al. 2011) Paraodiophyllochloa (Morrone et al. 2008), Cyphonanthus (Morrone et al. 2007), Apochloa (Sede et al. 2008), Renvoizea (Sede et al. 2008), Stephostachys (Zuloaga et al. 2010), Osvaldoa (Grande Allende 2014), Morronea (Scataglini \& Zuloaga 2013), Ocelochloa (Sede et al. 2009b) and Rugoloa (Acosta et al. 2014) have been segregated from the polyphyletic Panicum and described as new genera. Onorachis (Sede et al. 2009a) and Keratochlaena (Morrone \& Zuloaga 2009) were segregated from Streptostachys. Thrasya was merged within Paspalum (Denham 2005) and Ophiochloa was synonymized into Axonopus (López \& Morrone 2012). Cenchrus was transferred to Pennisetum (Chemisquy et al. 2010), and Rupichloa was recircumscribed to accommodate two species previously classified in Urochloa (Salariato et al. 2009).

In Bambusoideae, Cambajuva, a monotypic genus, was established to accommodate a distinctive species of Aulonemia (Viana et al. 2013). Olmeca fulgor and $O$. clarkiae were also segregated from Aulonemia (Ruiz-Sanchez et al. 2011). Dydymogonix was described based on two Andean species previously placed within Rhipidocladum (Tyrrell et al. 2012); Neurolepis was synonymized in Chusquea (Fisher et al. 2009) and Parianella was segregated from Pariana (Ferreira et al. 
2013). In addition, several new species from the Neotropics have been described in many genera in recent years.

Some regions in the Neotropics must be highlighted for the diversity and taxonomic importance they represent for Poaceae. The Cerrado (Central Brazilian savannas) holds an impressive diversity, especially of $\mathrm{C} 4$ species of Panicoideae and Chloridoideae; the Atlantic Forest, Guayana Shield and Andes are home to several endemic species; the Amazon Forest, although having not been satisfactorily inventoried, is also important for its diversity of habitats and species; and finally the Pampas is also highly diverse.

In the Cerrado ca. 700 species in 126 genera occur, which represents almost $50 \%$ of the total number cited to the country (Filgueiras et al. 2014). This amazing grass diversity can be associated with the variety of habitats which can be found in the Cerrado, such as riparian forests, grasslands, rocky outcrops, wetlands, among others, some of which are subjected to fire (Ribeiro \& Walter 1998). The three richest genera belong to Panicoideae: Paspalum (153 spp.), Axonopus (41 spp.) and Panicum (34 spp.), followed by Eragrostis (33 spp.; Chloridoideae), Digitaria (27 spp.; Panicoideae) and Aristida (26 spp.; Aristidoideae) (Filgueiras et al. 2014). The Campos Rupestres of the Espinhaço Range supports at least 36 endemic species besides peculiar genera such as Apochloa, Dichanthelium, Renvoizea and the monotypic Plagiantha tenella (Viana \& Filgueiras 2008). The quartzitic mountains of Chapada dos Veadeiros and the serpentine soils of Niquelândia region (state of Goiás) are also remarkable for their high levels of endemism. Filgeuirasia species, Actinonocladum verticillatum and Aulonemia effusa are a few bamboos adapted to fire.

The Atlantic Forest is one of the centers of diversity of bamboos in the world (Clark 1990; Judziewicz et al. 1999), with more than 160 native species, 135 of them endemic. It also houses a high diversity of Panicoideae (C3 taxa) adapted to shady habitats, such as Ichnanthus, Parodiophyllochloa, and Ocelochloa. In the high-altitude rocky outcrops some odd plants such as Glaziophyton mirabile; Cambajuva ulei, Cortaderia modesta, Apochloa lutzii, as well as several species of Chusquea sect. Swallenochloa and Dicahnthelium are found. The high-altitude forests associated with these mountains are also rich in endemic species of woody bamboo, mainly from Mesrostachys, Chusquea and Aulonemia, and some Panicoideae, such as Paradiophyllochloa penicillata, Ocelochloa latissima, and Hymenachne condensata. Colanthelia and Apoclada, endemic genera of bamboo, are also found in high-altitude forests. The central part of the Atlantic Forest (southern Bahia and Espírito Santo) is relevant to the diversity of grasses including the narrowendemic and threatened basal grass Anomochloa marantoidea Brongn.; herbaceous bamboo, such as Raddia, Piresia, Diandrolyra, Olyra, Parianella, and Eremitis, and woody ones in Alvimia, Atractantha, and Eremocaulon.

Davidse et al. (2007) cited 526 species to the Guayana Shield and most of the endemic ones are related to the Tepuis, such as Cortaderia roraimensis and other species in Arthrostylidium, Aulonemia, Dichanthelium, Chusquea, Myriocladus and Trichanthecium (Judziewicz \& Clark 1993; Judziewicz 1998; Davidse et al. 2007).

The Amazon Forest has not been satisfactorily inventoried but some typical components of the agrostological flora can be highlighted. The lowland forests are the main center of endemism of herbaceous bamboos in Pariana (ca. 30 spp.), besides Guadua (at least 10 spp.), Olyra (14 spp.), Raddiella (5 spp.) (Filgueiras et al. 2014) and the poorly known genera Agnesia and Froesiochloa (Judziewicz et al. 1999). Other species are typical from open, white-sand savanna vegetation, especially of the Neotropical genera Axonopus (Black 1963) and Paspalum (Filgueiras \& Davidse 1995) and the monotypic Arundoclaytonia dissimilis and Steyermakochloa angustifolia, which seem to be endemic to this habitat (Davidse \& Ellis 1984; Davidse \& Ellis 1987). The scarce mountains in the region are also diverse and include several species endemic to the iron rocky outcrops (canga vegetation) in the Serra dos Carajás (Burman \& Bastos 1988; Bastos 1990; Boechat \& LonghiWagner 1995), the sandstone formation of Serra do Cachimbo (Davidse et al. 2001) and the granitic rocky outcrops of Serra do Tumucumaque in Brazil, French Guiana, Guyana and Suriname.

The Andes are highly diverse in woody bamboo genera including the endemic genera Aulonemia, Arthrostylidium, Chusquea, Elytrostachys and Rhipidocladum, which are often associated with high-altitude forests and the Páramos (especially Chusquea and Aulonemia) (Clark 1990; Judziewicz et al. 1999). According to these authors, $90 \%$ of the bamboo species in the Andes are endemic. Some groups of grasses which 
are especially rich in temperate regions and belong mainly to Poideae are also well represented in the region, such as Poa, Festuca, Piptochaetium, and Cortaderia.

\section{Rapateaceae}

The Rapateaceae is a medium-sized family with less than 100 taxa in 17 genera which is mainly distributed in the Neotropical region but for one disjunct and monospecific genus in West Africa (Liberia and Sierra Leone) - Maschalocephalus (Berry 2007; Monteiro 2014; Stevenson et al. 1998). The hotspot for the taxonomic diversity of the family is the lowlands and highlands of the Guayana Shield. This area holds almost 80 species and some monospecific and endemic genera, such as Amphiphyllum, Marahuacaea, Phelpsiella, Potarophytum, and Windsoria (Berry 2004, 2007; Stevenson et al. 1998). The family is recorded in the Neotropics from Brazil, Bolivia, Colombia, French Guiana, Guyana, Panama, Peru, Suriname and Venezuela (Berry 2007).

The most diverse genera are Stegolepis and Rapatea with ca. 33 and 20 species, respectively, followed by Saxofridericia with 7 accepted species (Stevenson et al. 1998). The family is well represented in the understory of the Amazon Forest, where it is found in seasonally and permanently flooded areas and also on sandy soil in open areas. Almost 40 species in 9 genera are cited to Brazil (Monteiro 2014), 25\% of them in Rapatea. However, this number is probably underestimated because several species have been cited close to the Brazilian border but have not yet been collected in the country. Members of the family are also found in wet grasslands and bogs among rocky outcrops (Campos Rupestres) in the Cerrado vegetation but these areas are less diverse in number of species than the Amazon Forest.

Rapateaceae was previously placed in Commelinales with several other families that are now under Poales (Dahlgren et al. 1985). The family can be recognized by a combination of several embryological characters (Stevenson et al. 1998). It shares several anatomical, palynological and embryological features with Eriocaulaceae, Mayacaceae and Xyridaceae, and also with Commelinaceae which are nowadays placed in Commelinales. However, the most recent phylogenies based on molecular evidence have suggested a closer relationship with Bromeliaceae and Typhaceae (Chase et al. 2006; Givinish et al. 2010; Stevens 2001 onwards), this result is still not very well supported with morphological synapomorphies. The connection between Rapateaceae and Bromeliaceae emerging from molecular analysis is a revival of Pilger's (1930) interpretation of the group from almost 100 years ago. Givnish et al. (2010) suggest all three families (Bromeliaceae, Rapateaceae and Typhaceae) are part of an early divergent group in Poales.

The family was split by Maguire (1958, 1965 ) into two subfamilies (Saxofridericioideae and Rapateoideae) based on the number of ovules per carpel, placentation type, and morphology of seed, pollen and inflorescence (Stevenson et al. 1998). Givnish et al. (2000) pointed out that at least Rapateoideae is paraphyletic in their molecular studies. Later, a new classification for the family based on chloroplast analyses, showing three well supported subfamilies (Rapateoideae, Saxifridericioideae and Monotremoideae), was presented by Givnish et al. (2004).

Morphologically, Rapateaceae can be easily distinguished from other families in Poales by the inflorescence in a long scape often surrounded at the end by two large and basally broad bracts where the colored and actinomorphic (to slightly zygomorphic) flowers are inserted. The poricidal anthers (apical or subapical pores) and the trichomes which produce copious amount of a clear mucilage are also good characters to recognize the species of the family (Dahlgren et al. 1985; Stevenson et al. 1998, 2004).

\section{Thurniaceae}

The Thurniaceae is another small and traditionally monogeneric family in the Poales but it is poorly known morphologically (Kubitzki 1998). It has been placed in the cyperid clade as a sister-group of Cyperaceae-Juncaceae (BouchenakKhelladi et al. 2014). All three families share diffuse centromeres which is a unique character within the order (Dahlgren et al. 1985). Until very recently, Thurniaceae was considered endemic to the lowland forests of the Guayana Shield and found in eastern Colombia, southern Venezuela, northern Brazil, Guyana and Suriname (Kubitzki 1998; Stevenson 2004). However, Prionium, a genus formally placed in Juncaceae, seems to be better placed under Thurniaceae (Stevens 2001 onwards).

Plants are often big and clustered herbs with long and narrow-linear leaves which are strongly serrate along the margins. The inflorescence is 
glomerule-like at the end of a terminal branched or unbranched axis (scape) which holds hundreds of small, paleaceous flowers.

Only three species are known and all grow on sandy soil in habitats flooded by acidic ("black") waters such as streams and lakes in the Amazon Forest. The specimens have thick rhizomes and often form extensive monospecific stands at the edges of shallow lakes and streams. Thurnia jenmanii Hook. f. is a narrow endemic species found only in Suriname, T. polycephala Schnee occurs in Venezuela and Guyana while T. sphaerocephala (Rudge) Hook. f. is the most widespread species in the family (Alves 2014; Hokche et al. 2008; Riina \& Berry 2005).

The lack of information on the family is partly a result of its infrequent occurrence and distribution usually in remote areas of the Amazon Forest. Anatomical and molecular studies with T. sphaerocephala are under development by different teams in Brazil; however, the results are still preliminary and have not yet been published.

The Typhaceae is a small family in Poales of exclusively marsh and aquatic plants in two genera and 16-30 spp. The systematic position of the family is very controversial: it has been placed among the commelinoid clade, in Pandanales or more recently in Poales, where together with Bromeliaceae, it makes up the "bromeliad" clade (Bouchenak-Khelladi et al. 2014; Dahlgren et al. 1985; Kubitzki 1998).

It is distributed worldwide, though mainly occurs in North America and Eurasia (Stevenson 2004). In the Neotropics, Typha is the only native genus with 3-5 species recognized and widely distributed in different ecosystems. In Brazil, Sparganium can be found under cultivation (Bove 2014).

The species are always associated with flooded areas and form stands in shallow, slowmoving water and roadside ditches (Bove 2014; Carvalho et al. 2014; Hammel, 2003; Raechal \& Strong 2007; Stevenson 2004; Vargas 2007). The most common species in the Neotropics, T. dominguensis Pers., often forms extensive monospecific stands. Like the other species, it is a rapid colonizer of disturbed, polluted or newly formed wetlands.

Because of conspicuous morphological synapomorphies, it is not difficult to recognize a specimen as part of the genus but species delimitation has not yet been firmly established and there is frequent occurrence of interspecific hybridization (Kim \& Choi 2011). The genus is easily recognized as tall herbs with long, erect and narrow leaves and the typical cylindrical-brownish inflorescence at the end of a long and unbranched axis or scape (Stevenson 2004).

\section{Xyridaceae}

The Xyridaceae comprises ca. 425 species organized into five genera (Campbell 2004, 2005; Kral 1998). The family is pantropical with some extensions into the north-temperate zone and four genera restricted to South America. Xyris is a truly pantropical taxon, also diversified in Africa and Australia, with some species reaching temperate areas (Kral 1998). In the Neotropics, the family is often associated with wetlands and habitats affected by periodic fires (Campbell 2004) and is highly diverse in the Guayana Shield (Kral 2005; Kral \& Strong 2007).

In Brazil, Xyridaceae is represented by four genera and 186 species, of which 136 are endemic to the country. Almost $50 \%$ of them occur in the Cerrado and mainly in Campos Rupestres from Minas Gerais and Bahia. The preferential habitats are seasonal or permanently wet to moist grasslands, such as bogs and savannas and also humid rock outcrops at high elevations of central Brazil (Campbell 2004; Wanderley et al. 2014).

Xyridaceae usually emerges as a sister group of Eriocaulaceae, and also related to Mayacaceae in the xyrid clade (Givinish et al. 2010). However, its phylogenetic affinities have not been fully established and its monophyly has already been questioned (Davis et al. 2004). The most recent phylogenies support the family as a sister group of Eriocaulaceae (Bouchenak-Khelladi et al. 2014) or as sister of the clade formed by the restiids and graminids (Givnish et al. 2010). The lack of detailed phylogenies focusing on the Neotropical species will be addressed soon with ongoing researche (Motta 2014).

Plants usually have a capitate inflorescence at the end of a long and straight axis (or scape) and colorful, bisexual and zygomorphic flowers (Campbell 2004; Kral 1988, 1992, 1998; Mota 2014).

Xyris comprises ca. 400 species grouped into three sections. Xyris sect. Xyris is pantropical and has ca. 140 species with parietal placentation; $X$. sect. Pomatoxyris is the smallest section with 22 species restricted to Australia and has axillary placentation; $X$. sect. Nematopus is the most diverse 
with ca. 250 species mainly in South America and basal or central placentation (Kral 1998).

From the four genera endemic to South America, Abolboda is the most diverse with 23 species concentrated in the Guayana Shield. Orectanthe (2 spp.), Achlyphila and Aratitiyopea (1 sp. each) are also restricted to the same biogeographic area (Kral 2005; Kral \& Strong 2007).

The taxonomy of Neotropical Xyridaceae is strongly based on the Flora Brasiliensis (Seubert 1855) and Malme (1913a, b) studies. A few revisionary efforts have been done since then but have been mainly related to the Australian and African species (Conn \& Dust 1997; Dust \& Conn 1994; Lock 1999). Advances in Neotropical Xyridaceae are therefore based on many local floras and new species descriptions (e.g. Kral 1992, 1998, 2005; Kral \& Wanderley 1993, 1995; Motta \& Wanderley 2013, 2014; Silva \& Wanderley 2013; Wanderley 2010, 2011; Wanderley \& Silva 2009).

\section{Acknowledgments}

Financial support from Capes (M.A.), CNPq (M.A., M.T., R.C.F.), FAPERJ (M.T., R.C.F.), INCT-Herbário Virtual (M.A., M.T.) and NSF (M.A.). Thanks to S. Heald for the English review.

\section{References}

Abondanza, B. 2012. Revisão Taxonômica do complexo Aechmea coelestis (K. Koch) E. Morren (Bromeliaceae). Master Dissertation. Instituto de Botânica de São Paulo, São Paulo. 88p.

Acevedo-Rodriguez, P. \& Strong, M. 2012. Juncaceae. In: Acevedo-Rodriguez, P. \& Strong, M. (eds.). Catalogue of seed plants of West Indies. Smithsonian Contributions to Botany 98: 371.

Acosta, J.; Scataglini, M.; Reinheimer, R. \& Zuloaga, F. 2014. A phylogenetic study of subtribe Otachyriinae (Poaceae, Panicoideae, Paspaleae). Plant Systematics and Evolution 300: 2155-2166.

Adams, C. 1994. Cyperaceae. In: Davidse, G.; Sousa, M. \& Chater, A. (eds.). Flora Mesoamericana. Vol. 6. Universidad Autônoma de Mexico, Mexico DF. Pp. 402-485.

Almeida, V.; Costa, A.; Mantovani, A.; GonçalvesEsteves, V.; Arruda, R. \& Forzza, R. 2008. Morphological phylogenetics of Quesnelia (Bromeliaceae, Bromelioideae). Systematic Botany 34: 660-672. Balslev, H. 1998. Juncaceae. In: Kubitzki, K.; Huber, H.; Rudall, P.; Stevens, P. \& Stützel, T. Vascular flowering plants. Vol. 4. Springer, Berlin. Pp. 252-260.
Alves, M. 2014. Thurniaceae. In: Lista de Espécies da Flora do Brasil. Jardim Botânico do Rio de Janeiro. Available at $<$ http://floradobrasil.jbrj.gov.br/>. Access on 4 September 2014.

Alves, M. \& Luz, C., R. 2014. Juncaceae. In: Lista de Espécies da Flora do Brasil. Jardim Botânico do Rio de Janeiro. Available at $<$ http://floradobrasil. jbrj.gov.br/>. Access on 30 October 2014.

Alves, M.; Wanderley, M. \& Thomas, W. 2003. Padrões de ditribuicão das espécies neotropicais de Hypolytrum (Cyperaceae). Boletim de Botânica da Universidade de São Paulo 21: 265-276.

Alves, M.; Araujo, A.; Prata, A.; Vitta, F.; Hefler, S.; Trevisan, R.; Gil, A.; Martins, S. \& Thomas, W.W. 2009. Diversity of Cyperaceae in Brazil. Rodriguesia 60: 771-782.

Alves, M.; Wanderley, M. \& Thomas, W. 2003. Padrões de distribuição das espécies neotropicais de Hypolytrum (Cyperaceae). Boletim de Botânica da Universidade de São Paulo 21: 265-276.

Alves, M.; Hefler, S.; Trevisan, R.; Silva Filho, P.; Ribeiro, A. 2014. Cyperaceae. In: Lista de Espécies da Flora do Brasil. Jardim Botânico do Rio de Janeiro. Available at $<$ http://floradobrasil.jbrj.gov. br/>. Access on 4 September 2014.

Alves, M. \& Thomas, W. 2015. Pleurostachys (Cyperaceae): nomenclatural notes, geographical distribution and conservation status. Rodriguesia 66: 369-378.

Andrade, M.; Giulietti, A.; Rapini, A.; Queiroz, L.; Conceição, A.; Almeida, P. \& van den Berg, C. 2010. A comphreensive molecular phylogenetic analysis of Eriocaulaceae: evidence from nuclear (ITS) and plastid ( $p s b A$-trnH and trnL-trnF) DNA sequences. Taxon: 59: 379-388.

Araujo, A.; Prata, A.; Oliveira, A; Alves, M; Trevisan, R. \& Hefler, S. 2009. Cyperaceae. In: Batista, M. \& Cavalcanti, T. (eds.). Flora do Distrito Federal. Vol. 7. Embrapa, Brasília. Pp. 41-16.

Balslev, H. 1996. Juncaceae. Flora Neotropica Monograph 68: 1-167.

Balslev, H. 1998. Juncaceae. In: Kubitzki, K.; Huber, H.; Rudall, P.; Stevens, P. \& Stützel, T. (eds.). Vascular flowering plants. Vol. 4. Springer, Berlin. Pp. 252-260.

Balslev, H. 2004. Juncaceae. In: Smith, N.; Mori, S.; Henderson, A.; Stevenson, D. \& Heald, S. (eds.). Flowering plants of the neotropics. Princeton University Press, Princeton. Pp. 450-451.

Balslev, H. \& Zuluaga, A. 2009. Juncaceae. In: Betancur, J.; Galleano, G. \& Aguirre-C, J. (eds.). Flora of Colombia. Vol. 26. Universidad Nacional de Colombia, Bogotá. Pp. 1-79.

Barbará, T.; Martinelli, G.; Fay, M.; Mayo, S. \& Lexer, C. 2007. Population differentiation and species cohesion in two closely related plants adapted to 
neotropical high-altitude 'inselbergs', Alcantarea imperialis and Alcantarea geniculata (Bromeliaceae). Molecular Ecology 16: 1981-1992.

Barbará, T.; Martinelli, G.; Palma-Silva, C.; Fay, M.; Mayo, S. \& Lexer, C. 2009. Genetic relationships and variation in reproductive strategies in four closely related bromeliads adapted to neotropical 'inselbergs': Alcantarea glaziouana, A. regina, A. geniculata and $A$. imperialis (Bromeliaceae). Annals of Botany 103: 65-77.

Barfuss, M.; Samuel, R.; Till, W. \& Stuessy, T. 2005. Phylogenetic relationships in subfamily Tillandsioideae (Bromeliaceae) based on DNA sequence data from seven plastid regions. American Journal of Botany 92: 337-351.

Barker, N.; Galley, C.; Verboom, G.; Gilbert, M. \& Linder, H. 2007. The phylogeny of the austral grass subfamily Danthonioideae: evidence from multiple data sets. Plant Systematics and Evolution 264: 135-156.

Barros, J. \& Costa, A. 2008. O gênero Billbergia Thunb. (Bromeliaceae) no Estado do Rio de Janeiro. Acta Botanica Brasilica 22: 1172-1192.

Bastos, M. 1990. Nota prévia sobre uma gramineae nova da Serra dos Carajás, Pará. Boletim do Museu Paraense Emílio Goeldi, Série Botânica 6: 137.

Bauters, K.; Larridon, I.; Reynders, M.; Asselman, P.; Vrijdaghs, A.; Muasya, A.; Simpson, D. \& Goetghebeur, P. 2014. A new classification for Lipocarpha and Volkiella as infrageneric taxa of Cyperus s.l. (Cypereae, Cyperoideae, Cyperaceae): insights from species tree reconstruction supplemented with morphological and floral developmental data. Phytotaxa 16: 1-85.

Benzing, D. 2000. Vascular epiphytes: general biology and related biota. Cambridge University Press, Cambridge. 354p.

Berry, P. 2004. Rapateaceae. In: Steyermark, J.; Berry, P. \& Holst, B. (eds.). Flora of the Guayana Venezuelan. Vol. 8. Missouri Botanical Garden, Saint Louis. Pp. 413-472.

Berry, P. 2007. Rapateaceae. In: Kunk, V.; Hallowell, T.; Berry, P.; Kelloff, C. \& Alexander, S. (eds.). Checklist of the plants of the Guayana Shield. Washington Museum of Natural History, Washington. Pp. 173175.

Black, G. 1963. Grasses of the genus Axonopus (a taxonomic treatment). Advancing Frontiers of Plant Sciences 5: 1-186.

Bongard, M. 1831. Essai monographique sur les espèces d'Ériocaulon du Brésil Mémoires de 1>Academie Imperiale des Sciences de St.-Petersbourg. Sixieme Serie. Sciences Mathematiques 1:601-655.

Bouchenak-Khelladi, Y.; Verbon, G.; Hodkinson, T.; Salamin, N.; Francois, O; Chongaile, G. \& Savolainen, V. 2009. The origins and diversification of $\mathrm{C}_{4}$ grasses and savanna-adapted ungulates. Global Change Biology 10: 2397-2417.
Bouchenak-Khelladi, Y.; Muasya, A. \& Linder, H. 2014. A revised evolutionary history of Poales: origins and diversification. Botanical Journal of the Linnean Society 175: 4-16.

Bove, C. 2014. Typhaceae. In: Lista de Espécies da Flora do Brasil. Jardim Botânico do Rio de Janeiro. Available at $<$ http://floradobrasil.jbrj.gov.br/>. Access on 4 September 2014.

Büneker, H.; Pontes, R.; Soares, K.; Witeck, L. \& Longhi, S.J. 2013. Uma nova espécie reófita de Dyckia (Bromeliaceae, Pitcairnioideae) para a flora do Rio Grande do Sul, Brasil. Revista Brasileira de Biociências 11: 284-289.

Boechat, S. \& Longhi-Wagner, H. 1995. O gênero Sporobolus (Poaceae: Chloridoideae) no Brasil. Acta Botanica Brasilica 9: 21-86.

BPG - Bamboo Phylogeny Group. 2012. An updated tribal and subtribal classification for the Bambusoideae (Poaceae). In: Proceedings of the 9th World Bamboo Congress. Antwerp, Belgium. Pp. 3-27.

Burman, A. \& Bastos, M. 1988. A new species of Thrasya H.B.K. (Gramineae) from Brazil. Boletim do Museu Paraense Emílio Goeldi. Série Botânica 4: 235-241.

Camelbecke, C.; Goetghebeur, P.; González-Eliazondo, M.; Kerns, D.; Kral, R.; Reznicek, A.; Simpson, D.; Strong, M.; Thomas, W. \& Turcker, G. Cyperaceae. 2007. In: Kunk, V.; Hallowell, T.; Berry, P.; Kelloff, C. \& Alexander, S. Checklist of the plants of the Guayana Shield. Washington Museum of Natural History, Washington. Pp. 88-103.

Campbell, L. 2004. Anatomy and Systematics of Xyridaceae, with special reference to Aratitiyopea Steyerm. \& P.E. Berry. PhD Thesis. City University of New York, New York. 364p.

Campbell, L. 2005. Contributions towards a monograph of Xyridaceae: a revised nomenclature of Abolboda. Harvard Papers in Botany 10: 137-145.

Carvalho, M. 2007. Estudos taxonômicos em Mayacaceae Kunth. Master Dissertation. Universidade Estadual Paulista Julho de Mesquita Filho, Rio Claro. Pp. 1-78.

Carvalho, M; Lima, C.; Oliveira, R. \& Guilietti, A. 2014. Flora da Bahia Typhaceae. Sitientibus, série Ciências Biológicas 14: on line first. DOI: 10.13102/scb420.

Chase, M. 2005. Monocotiledons relationships: an overview. American Journal of Botany 91: 1645-55.

Chase, M.; Fay, M.; Devey, D.; Maurin, O.; Rønsted, N.; Davies, T.; Pillon, Y.; Petersen, G.; Seberg, O.; Tamura, M.; Asmussen, C.; Hilu, K; Borsch, T.; Davis, J.; Stevenson, D.; Pires, J.; Givnish, T.; Sytsma, K.; McPherson, M.; Graham, S. \& Rai, H. 2006. Multigene analyses of monocot relationships: a summary. Aliso 23: 62-74.

Chemisquy, M.; Giussani, L.; Scataglini, M.; Kellogg, E. \& Morrone, O. 2010. Phylogenetic studies favour the unification of Pennisetum, Cenchrus and Odontelytrum (Poaceae): a combined nuclear, plastid and morphological analysis, and nomenclatural 
combinations in Cenchrus. Annals of Botany 106: 107-130.

Cialdella, A.; Sede, S.; Romaschenko, K.; Peterson, P.; Soreng, R.; Zuloaga, F. \& Morrone, O. 2014. Phylogeny of Nassella (Stipeae, Pooideae, Poaceae) based on analyses of chloroplast and nuclear ribosomal DNA and morphology. Systematic Botany 39: 814-828.

Clark, L. 1990. Diversity and biogeography of neotropical bamboos (Poaceae: Bambusoideae). Acta Botanica Brasilica 4: 125-132.

Clayrton, W.; Vorontsova, M.; Harman, K. \& Williamson, H. 2006. GrassBase - The Online World Grass Flora. Available at $<$ http://www.kew.org/data/grasses-db. html $>$. Access on 19 November 2014.

Coffani-Nunes, J. 2004. Revisão Taxonômica e Filogenia de Portea_Brong. ex K. Koch (Bromelioideae Bromeliaceae). PhD Thesis. Universidade de São Paulo, São Paulo. 96p.

Coffani-Nunes, J.; Versieux, L.; Wanderely, M. \& Pirani, J.R. 2010. Flora da Serra do Cipó, Minas Gerais: Bromeliaceae - Tillandsioideae. Boletim de Botânica da Universidade de São Paulo 1: 35-54.

Columbus, J.; Cerros-Tlatilpa, R.; Kinney, M.; SiqueirosDelgado, M.; Bell, H.L.; Griffith, M. \& RefulioRodríguez, N. 2007. Phylogenetics of Chloridoideae (Gramineae): A preliminary study based on the nuclear ribosomal internal transcribed spacer and chloroplast trnL-F sequences. Aliso 23: 565-579.

Conn, B. \& Doust, A. 1997. Xyris L. section Pomatoxyris Endl. (Xyridaceae) in Australia. Australian Systematic Botany 10: 189-248.

Coser, T.; Paula, C. \& Wendt, T. 2010. Bromeliaceae Juss. nos campos rupestres do Parque Estadual do Itacolomi, Minas Gerais, Brasil. Rodriguesia 61: 261-280.

Costa, A.; Gomes-da-Silva, J. \& Wanderley, M. 2014. Vriesea (Bromeliaceae, Tillandsioideae): taxonomic history, and morphology of the Brazilian lineage. The Journal of the Torrey Botanical Society 141:338-352.

Costa, A.; Rodrigues, P. \& Wanderley, M. 2009. Morphometric analysis and taxonomic revision of the Vriesea paraibica complex (Bromeliaceae). Botanical Journal of the Linnean Society 159: 163181.

Costa, A. \& Wendt, T. 2007. Bromeliaceae na Região de Macaé de Cima, Nova Friburgo, Rio de Janeiro. Rodriguesia 58: 905-939.

Costa, F. 2006. Three new species of Actinocephalus Sano (Eriocaulaceae) from Minas Gerais, Brazil. Novon 16: 212-215

Costa, F. \& Sano, P. 2013. New Circumscription of the Endemic Brazilian Genus Actinocephalus (Eriocaulaceae). Novon 22: 281-287.

Davidse, G. \& Ellis, R. 1987. Arundoclaytonia, a new genus of the Steyermarkochloeae (Poaceae:
Arundinoideae) from Brazil. Annals of the Missouri Botanical Garden 74: 479-490.

Davidse, G. \& Ellis, R.P. 1984. Steyermarkochloa unifolia, a new genus from Venezuela and Colombia (Poaceae: Arundinoideae: Steyermarkochloeae). Annals of the Missouri Botanical Garden 71: 994-1012.

Davidse, G.; Judziewicz, E.J. \& Zuloaga, F.O. 2007. Poaceae. In: Funk, V.; Hollowell, T.; Berry, P.; Kelloff, C. \& Alexander, S. Checklist of the Plants of the Guiana Shield (VENEZUELA: Amazonas, Bolivar, Delta Amacuro; Guyana, Surinam, French Guiana). Contributions from the United States National Herbarium 50: 149-172.

Davidse, G.; Morrone, O. \& Zuloaga, F. 2001. Two new species of Paspalum (Poaceae: Panicoideae) from Brazil. Novon 11: 389-394.

Davis, T.; Baraclough, T.; Chase, M.; Soltis, P.; Sooltis, D. \& Savaiolen, V. 2004. Darwin's abominable mystery: insights from a supertree of Angiosperm. Proceedings of the National Acady of Science of the USA 101: 1904-1909.

Dahlgren, R.; Clifford, H. \& Yeo, P. 1985. The families of the monocotyledons. Springer, New York. 520p.

Daly, D. \& Mitchell, J. 2000. Lowland vegetation of tropical South America. In: Lentz, D. (ed.). Imperfect Balance: landscape transformations in the preColumbian Americas. Columbia University Press, New York. Pp. 391-454.

Denham, S. 2005. Revision sistemática del subgénero Harpostachys de Paspalum (Poaceae: Panicoideae: Paniceae). Annals of the Missouri Botanical Garden 92: 463-532.

Doust, A. \& Conn, B. 1994. Xyris L. section Xyris (Xyridaceae) in Australia. Australian Systematic Botany 7: 455-484.

Echternacht, L.; Trovó, M. \& Sano P. 2011. Two new species of Actinocephalus (Eriocaulaceae) from Minas Gerais, Brazil. Phytotaxa 27: 26-36.

Echternacht, L.; Sano, P.; Trovó, M. \& Dubuisson, J-Y. 2011. Phylogenetic analysis of the Brazilian microendemic Paepalanthus subgenus Xeractis (Eriocaulaceae) inferred from morphology. Botanical Journal of the Linnean Society 167: 137-152.

Echternacht, L.; Trovó, M. \& Sano, P. 2012. Paepalanthus rectifolius, a new name in Eriocaulaceae (Poales). PhytoKeys 10: 7-12.

Echternacht, L.; Sano P.; Bonillo, C.; Cruaud, C.; Couloux, A.; Dubuisson, J-Y. 2014. Phylogeny and Taxonomy of Syngonanthus and Comanthera (Eriocaulaceae): evidence from expanded sampling. Taxon 63: 47-63.

Escobedo-Sarti, J.; Ramírez, I.; Leopardi C.; Carnevali G.; Magallón S.; Duno R. \& Mondrágon, D. 2013. A phylogeny of Bromeliaceae (Poales, Monocotyledonae) derived from and evaluation of nine supertree methods. Journal of Systematics and Evolution 51: 743-757. 
Esteves, E. \& Gouda, E. 2014. A new Dyckia species (Bromeliaceae, Pitcairnioideae) from the Brazilian Northeastern region. Phytotaxa 164: 296-300.

Faria, A.; Wendt, T. \& Brown, G. 2004. Cladistic relationships of Aechmea (Bromeliaceae, Bromelioideae) and allied genera. Annals of the Missouri Botanical Garden 91: 303-319.

Faria, A.; Wendt, T. \& Brown, G. 2010. A revision of Aechmea subgenus Macrochordion (Bromeliaceae) based on phenetic analyses of morphological variation. Botanical Journal of the Linnean Society 162: $1-27$

Ferreira, F.; Berg, C.; Hollowell, V. \& Oliveira, R. 2013. Parianella (Poaceae, Bambusoideae): morphological and biogeographical information reveals a new genus of herbaceous bamboos from Brazil. Phytotaxa 77: 27-32.

Filgueiras, T.S. \& Davidse, G. 1995. Two new species of Paspalum (Poaceae: Paniceae) from Brazil. Novon 5: 146-151.

Filgueiras, T.; Longhi-Wagner, H.; Viana, P.; Zanin, A.; Oliveira, R.; Canto-Dorow, T.; Rodrigues, R.; Santos, A.; Welker, C.; Ferreira, F.; Carvalho, M.; Silva, A.; Mota, A.; Valls, J.F.M.; Shirasuna, R.; Reis, P.; Dórea, M.; Silva, C. \& Oliveira, R. 2014. Poaceae. In: Lista de Espécies da Flora do Brasil. Jardim Botânico do Rio de Janeiro. Available at $<$ http://floradobrasil.jbrj.gov.br/>. Access on 30 October 2014.

Fiaschi, P. \& Pirani, J. 2009. Review of plant biogeographic studies in Brazil. Journal of Systematics and Evolution 47: 477-496.

Fisher, A.; Clark, L. \& Kelchner, S. 2014. Molecular phylogeny estimation of the bamboo genus Chusquea (Poaceae: Bambusoideae: Bambuseae) and description of two new subgenera. American Journal of Botany 39: 829-844.

Fisher, A.; Triplett, J.; Ho, C.; Schiller, A.; Oltrogge, K.; Schroder, E.; Kelchner, S. \& Clark, L. 2009. Paraphyly in the bamboo subtribe Chusqueinae (Poaceae: Bambusoideae) and a revised infrageneric classification for Chusquea. Systematic Botany 34: 673-683.

Forzza, R. 2005. Revisão taxonômica de Encholirium Mart. ex Schult. \& Schult. f. (Pitcairnioideae Bromeliaceae). Boletim de Botânica da Universidade de São Paulo 23: 1-49.

Forzza, R.; Costa, A.; Leme, E.; Versieux, L.; Wanderley, M.; Louzada, R.; Monteiro, R.; Judice, D.; Fernandez, E.; Borges, R.; Penedo, T.; Monteiro, N. \& Moraes, M. 2013. Bromeliaceae. In: Martinelli, G. \& Moraes, M. Livro vermelho da Flora do Brasil. Andrea Jakobson Estúdio Editorial \& Jardim Botânico do Rio de Janeiro, Rio de Janeiro. Pp. 315-396.

Forzza, R.; Costa, A.; Siqueira Filho, J.; Martinelli, G.; Monteiro, R.; Santos-Silva, F.; Saraiva D.; Paixão, B.; Louzada, R.; Versieux, L. 2014. Bromeliaceae.
In: Lista de Espécies da Flora do Brasil. Jardim Botânico do Rio de Janeiro. Available at $<$ http:// floradobrasil.jbrj.gov.br/jabot/floradobrasil/FB66>. Access on 10 October 2014.

Forzza, R. \& Wanderley M. 1998. Flora da Serra do Cipó, Minas Gerais: Bromeliaceae - Pitcairnioideae. Boletim de Botânica Universidade de São Paulo 17: 255-270

Gilmartin, A. \& Brown, G. 1987. Bromeliales, related Monocots, and resolution of relationships among Bromeliaceae subfamilies. Systematic Botany 12: 493-500.

Giulietti, A. 1978. Modificações taxonômicas no gênero Eriocaulon L. Boletim de Botânica da Universidade de São Paulo 6: 39-48.

Giulietti, A. \& Pirani, J. 1988. Patterns of geographic distribution of some species from the Espinhaco Range, Minas Gerais and Bahia, Brasil. In: Heyer, W. \& Vanzolini, P. (eds.). Proceedings of a workshop on Neotropical distribution patterns. Academia Brasileira de Ciências, Rio de Janeiro. Pp. 39-69.

Giulietti, A.; Wanderley, M.; Longhi-Wagner, H.; Pirani, J. \& Parra, L. 1996. Estudo em "sempre-vivas": taxonomia com ênfase nas espécies de Minas Gerais, Brasil. Acta Botânica Brasílica 10: 329-377.

Giulietti, A. \& Hensold, N. 1990. Padrões de distribuição geográfica dos gêneros de Eriocaulaceae. Acta Botanica Brasilica 4:133-158.

Giulietti, A. \& Miranda, E. 2009. Five new taxa in Eriocaulaceae from the Chapada Diamantina of Bahia, Brazil. Kew Bulletin 64: 525-536.

Giulietti,A.; Amaral. M. \& Bittrich, V. 1995. Phylogenetic analysis of inter- and infrageneric relationships of Leiothrix Ruhl. (Eriocaulacaceae). Kew Bulletin 50: 55-71.

Giulietti, A.; Andrade, M.; Scatena, V.; Trovó, M.; Coan, A.; Sano, P.; Santos, F.; Borges, R. \& van den Berg, C. 2012. Molecular phylogeny, morphology and their implications for the taxonomy of Eriocaulaceae. Rodriguésia 63: 1-19.

Giulietti, A.; Harley, R.; Queiroz, L.; Wanderley, M. \& van den Berg, C. 2005. Biodiversidade e conservação das plantas no Brasil. Megadiversidade 1: 52-61.

Giulietti, A.; Sano, P.; Costa, F.; Parra, L.; Echternacht, L.; Tissot-Squalli, M.; Trovó, M.; Watanabe, M.; Freitas, M. \& Hensold, N. 2014. Eriocaulaceae. In: Lista de Espécies da Flora do Brasil. Available at $<$ http://floradobrasil.jbrj.gov.br/2014/>. Access on 10 October 2014.

Giulietti, A.; Scatena, V.; Sano, P.; Parra, L.; Queiroz, L.; Harley, R.; Menezes, N.; Iseppon, A.; Salatino, A.; Salatino, M.L.; Vilegas, W.; Santos, L.; Ricci, C.; Bonfim M. \& Miranda, E. 2000. Multidisciplinary studies on Neotropical Eriocaulaceae In: Wilson, K. \& Morrison, P. (eds.). Monocots: Systematics and Evolution. CSIRO, Collingwood. Pp. 580-589. 
Givnish, T.; Millam, K.; Evans, T.; Hall, J.; Pires, J.; Berry, P. \& Systma, K. 2004. Ancient vicariance or recent long-distance dispersal? Inferences about phylogeny and south-american disjunctions in Rapateaceae and Bromeliaceae based on $n d h \mathrm{~F}$ sequence data. International Journal of Plant Sciences 165 (4 suppl.): S35- S54.

Givnish, T.; Millam, K.; Berry, P. \& Sytsma, K. 2007. Phylogeny, adaptive radiation, and historical biogeography of Bromeliaceae inferred from ndhF sequence data. Aliso 23: 3-26.

Givnish T.; Ames, M.; McNeal, J.; McKain, M.; Steele, P.; de Pamphilis, C.; Graham, S.; Pires, J.; Stevenson, D.; Zomlefer, W.; Briggs, B.; Duvall, M.; Moore, M.; Heaney, J.; Soltis, D.; Soltis, P.; Thiele, K. \& Leebens-Mack, J. 2010. Assembling the tree of the monocotyledons: plastome sequence phylogeny and evolution of Poales. Annales of the Missouri Botanical Garden 97:584-616.

Givnish, T.; Barfuss, M.; Van Ee, B., Riina, R., Schulte, K., Horres, R., Gonsiska, P.; Jabaily, R.; Crayn, D.; Smith, J.; Winter, K.; Brown, G.; Evans, T.; Holst, B.; Luther, H., Till, W., Zizka, G., Berry, P. \& Sytsma, K. 2011. Phylogeny, adaptive radiation, and historical biogeography in Bromeliaceae: Insights from an eight-locus plastid phylogeny. American Journal of Botany 98: 872-895.

Goetghebeur, P. 1998. Cyperaceae. In: Kubitzki, K.; Huber, H.; Rudall, P.; Stevens, P. \& Stützel, T. (eds.). Vascular flowering plants. Vol. 4. Springer-Verlag, Berlin. Pp. 141-189.

Gomes-da-Silva, J. 2009. Análise filogenética e circunscrição taxonômica de Vriesea Lindley (Bromeliaceae: Tillandsioideae), baseado em dados morfológicos e moleculares. PhD Thesis. Universidade Federal do Rio de Janeiro, Rio de Janeiro. 222p.

Gomes-da-Silva, J. \& Costa, A. 2011. A taxonomic revision of Vriesea corcovadensis group (Bromeliaceae: Tillandsioideae) with description of two new species. Systematic Botany 36: 291-309.

Gomes-da-Silva, J.; Vargens, F.; Arruda R. \& Costa, A. 2012. A morphological cladistic analysis of the Vriesea corcovadensis group (Bromeliaceae: Tillandsiodeae), with anatomical descriptions: New evidence of the non-monophyly of the genus. Systematic Botany 37: 641-654.

Goméz-Laurito, J. 2003. Cyperaceae. In: Hammel, B.; Grayum, M.; Herrera, C. \& Zamora, N. (eds.). Manual de las plantas de Costa Rica. Monographs in Systematic Botany, Missouri Botanical Garden 93: 458-551.

Govaerts, R.; Simpson, D.; Bruhl, J.; Egorova, T.; Goetghebeur \& Wilson, K. 2007. World checklist of Cyperaceae. Kew Gardens, London. 765p.

GPWG - Grass Phylogeny Working Group I. 2001. Phylogeny and subfamilial classification of the grasses (Poaceae). Annals of the Missouri Botanical Garden 88: 373-457.

GPWG - Grass Phylogeny Working Group II. 2011. New grass phylogeny resolves deep evolutionary relationships and discovers $\mathrm{C} 4$ origins. New Phytologist 193: 304-312.

Grande Allende, J.R. 2014. Novitates Agrostologicae, IV. Additional segregates from Panicum incertae sedis. Phytoneuron 22: 1-6.

Guaglianone, R.; Marchesi, E.; Marticonera, C.; Araújo, A.C.; Mereles, F.; Alves, M.; Doohge, S.; González-Eliazondo; M.; Hefler, S.; López, M.; López-Sepulveda, P.; Trevisan, R. \& Wheeler, G. 2008. Cyperaceae. In: Zuloaga, F.; Morrone, O. \& Belgrano, M. (eds.). Catálogo de las Plantas Vasculares del Cono Sur (Argentina, Sur de Brasil, Chile, Paraguay y Uruguay). Vol. 1. Missouri Botanical Garden, Saint Louis. Pp. 302-401.

Guarçoni, E.; Paula, C. \& Costa, A. 2010. Bromeliaceae do Parque Estadual da Serra do Rola-Moça, Minas Gerais. Rodriguesia 61: 467-490.

Hammel, B. 2003. Typhaceae. In: Hammel, B.; Grayum, M.; Herrera, C. \& Zamora, N. (eds.). Manual de las plantas de Costa Rica. Monographs in Systematic Botany, Missouri Botanical Garden 93: 841-845.

Hammel, B. 2003a. Juncaceae. In: Hammel, B.; Grayum, M.; Herrera, C. \& Zamora, N. (eds.). Manual de las plantas de Costa Rica. Monographs in Systematic Botany, Missouri Botanical Garden 93: 613-617.

Hensold, N. 1988. Morphology and systematics of Paepalanthus subgenus Xeractis (Eriocaulaceae). Systematic Botany Monographs 23:. 1-150.

Hensold, N. 1991. Revisionary studies in the Eriocaulaceae of Venezuela. Annals of the Missouri Botanical Garden 78: 424-440.

Hensold, N. 2004. Two New species and a New combination in South American Eriocaulaceae. Novon 14: 302-308.

Hensold, N. \& Giulietti, A. 1991. Revision and redefinition of the genus Rondonanthus Herzog (Eriocaulaceae). Annals of the Missouri Botanical Garden 78: 441-459.

Hensold, N.; Oliveira, A. \& Giulietti, A. 2012. Syngonanthus restingensis (Eriocaulaceae): A remarkable new species endemic to Brazilian coastal shrublands. Phytotaxa 40: 1-11.

Hmeljevski, K.; Freitas, L.; Domingues, R.; Pereira, A.; Cancio, A.; Andrade, A.; Machado, M.; Viccini, L. \& Forzza, R. 2014. Conservation assessment of an extremely restricted bromeliad highlights the need for population-based conservation on granitic inselbergs of the Brazilian Atlantic Forest. Flora (Jena) 209: 250-259.

Hokche, O.; Berg, P. \& Huber, O. 2008. Nuevo catálogo de la flora vascular de Venezuela. Fundación Instituto Botánico de Venezuela, Caracas. 859p. 
Horres, R.; Zizka, G.; Kahl, G. \& Weising, K. 2000. Molecular Phylogenetics of Bromeliaceae: Evidence from $t r n \mathrm{~L}$ (UAA) Intron Sequences of the Chloroplast Genome. Plant Biology 2: 306-315.

Horres R.; Schulte, K.; Weising K. \& Zizka, G. 2007. Systematics of Bromelioideae (Bromeliaceae) evidence from molecular and Anatomical studies. Aliso 23: 27-43.

Huber, O. 1995. Geographical and physical features. In: Berry, P.; Yatskievych, K. \& Holst, B. (eds.). Flora of the Guayana Venezuelana. Vol. 1. Missouri Botanical Garden, Saint Louis. Pp.1-51.

Judd, W.; Campbell, C.; Kellog, E.; Stevens, P. \& Donoghue, M. 2007. Plant Systematics: A phylogenetic approach. Sinauer Associates, Sunderland. 464p.

Judziewicz, E. 1998. A revision of Myriocladus (Poaceae: Bambusoideae: Bambuseae). Brittonia 50: 430-446.

Judziewicz, E. \& Clark, L. 1993. The South American species of Arthrostylidium (Poaceae: Bambusoideae: Bambuseae). Systematic Botany 18: 80-99.

Judziewicz, E.; Clark, L.; Londoño, X. \& Stern, M. 1999. American Bamboos. Smithsonian Books, Washington DC. 392p.

Judziewicz, E.; Soreng, R.; Davidse, G.; Peterson, P.; Filgueiras, T. \& Zuloaga, F. 2000. Catalogue of New World Grasses (Poaceae): I. Subfamilies Anomochloideae, Bambusoideae, Ehrhartoideae, and Pharoideae. Contributions from the United States National Herbarium 39: 1-128.

Kearns, D.; Thomas, W.; Turcker, G.; Kral, R.; Camelbecke, K.; Simpson, D.; Reznicek, A.; González-Eliazondo, M.; Strong, M. \& Goetghebeur, P. 1998. Cyperaceae. In: Steyermark, J.; Berry, P. \& Holst, B. (eds.). Flora of the Guayana Venezuelana. Vol. 4. Missouri Botanical Garden, Saint Louis. Pp. 486-663.

Kim, C. \& Choi, H. 2011. Molecular systematics and character evolution of Typha (Typhaceae) inferred from nuclear and plastid DNA sequence data. Taxon 60: 1417-1428.

Koernicke, F. 1863. Eriocaulaceae. In: Martius, C.F.P. \& Eichler, A.W. Flora Brasiliensis. München, Wien, Leipzig. Vol. 3, pp. 273-307.

Kral, R. 1998. The genus Xyris (Xyridaceae) in Venezuela and contiguous Northern South America. Annals of the Missouri Botanical Garden. 75: 522-722.

Kral, R. 2005. Xyridaceae. In: Steyermark, J.; Berry, P. \& Holst, B. Flora of the Guayana Venezuelana. Vol. 9. Missouri Botanical Garden, Saint Louis. Pp. 526-574.

Kral, R. 1992. A Treatment of American Xyridaceae exclusive of Xyris. Annals of the Missouri Botanical Garden 79: 819-885.

Kral, R. \& Strong, M. 2007. Xyridaceae. In: Kunk, V.; Hallowell, T.; Berry, P.; Kelloff, C. \& Alexander,
S. Checklist of the plants of the Guayana Shield. Washington Museum of Natural History, Washington. Pp. 178-182.

Kral, R. \& Wanderley, M. 1993. Five new taxa of Xyris (Xyridaceae) from Brazil. Kew Bulletim 48: 577-588.

Kral, R. \& Wanderley, M. 1995. Xyridaceae. In: Stannard, B.L. Flora of Pico das Almas, Chapada da Diamantina, Bahia, Brazil. Kew Gardens, London. Pp. 781-802.

Krapp, F.; Pinangé, D.; Benko-Iseppon, A.; Leme, E. \& Weising, K. 2014. Phylogeny and evolution of Dyckia (Bromeliaceae) inferred from chloroplast and nuclear sequences. Plant Systematics and Evolution 300: 1591-1614.

Kubitzki, K. 1998. Thurniaceae. In: Kubitzki, K.; Huber, H.; Rudall, P.; Stevens, P. \& Stützel, T. (eds.). Vascular flowering plants. Vol. 4. Springer-Verlag, Berlin. Pp. 455-458.

Kubitzki, K. 1998. Typhaceae. In: Kubitzki, K.; Huber, H.; Rudall, P.; Stevens, P. \& Stützel, T. (eds.). Vascular flowering plants. Vol. 4. Springer-Verlag, Berlin. Pp. 459-461.

Larridon, I.; Bauters, K.; Reynders, M.; Huygh, W.; Muasya, A.; Simpson, D. \& Goetghebeur, P. 2013. Towards a new classification of the giant paraphyletic genus Cyperus (Cyperaceae): phylogenetic relationships and generic delimitation in C4 Cyperus. Botanical Journal of the Linnean Society 172: 106-126.

Larridon, I.; Bauters, K.; Reynders, M.; Huygh, W. \& Goetghebeur, P. 2014. Taxonomic changes in $\mathrm{C}_{4 \text { cyperus }}$ (Cypereae, Cyperoideae, Cyperaceae): reducing the sedge genera Ascolepis, Kyllinga and Pycreus into Cyperus sensu lato. Phytotaxa 166:33-48.

Lavor, P.; van den Berg, C.; Jacob, C.; Carmo, F. \& Versieux, L. 2014. Population genetics of the endemic and endangered Vriesea minarum (Bromeliaceae) in the iron quadrangle Espinhaço Range, Brazil. American Journal of Botany 101: 1167-1175.

LEFB - Lista de Espécies da Flora do Brasil. Jardim Botânico do Rio de Janeiro. Available at $<$ http://floradobrasil.jbrj. gov.br/>. Access on 4 September 2014.

Leme, E. 1997. Canistrum: Bromélias da Mata Atlântica. Ed. Salamandra, Rio de Janeiro. 107p.

Leme, E. 1998. Canistropsis: Bromélias da Mata Atlântica. Ed. Salamandra, Rio de Janeiro. 143p.

Leme, E. 2000. Nidularium: Bromélias da Mata Atlântica. Hamburg Donneley Editora Gráfica, Rio de Janeiro. 264p.

Leme, E.; Fontana, A. \& Halbritter, H. 2010. Three new Pitcairnia species (Bromeliaceae) from the inselbergs of Espírito Santo, Brazil. Systematic Botany 35: 487-496.

Linder, H. \& Rudall, P. 2005. Evolutionary history of Poales. Annual Review Ecology, Evolution and Systematics 36:107-24. 
Linder, H.; Baeza, C.; Barker, N.; Galley, C.; Humphreys, A.; Lloyd, K.; Orlovich, D.; Pirie, M.; Simon, B.; Walsh, N. \& Verboom, G. 2010. A generic classification of the Danthonioideae (Poaceae). Annals of the Missouri Botanical Garden 97: 306-364.

Lock, J. 1999. A Synopsis of Xyris (Xyridaceae) in South-Central Africa. Kew Bulletin 54: 301-326.

Longhi-Wagner, H. \& Oliveira, R. 2011. Neotropical Poaceae In: Milliken, W.; Klitgård, B. \& Baracat, A. (2009 onwards), Neotropikey - Interactive key and information resources for flowering plants of the Neotropics. Available at <http://www.kew.org/ science/tropamerica/neotropikey/families/Poaceae. $\mathrm{htm}>$. Access on 30 October 2014.

López, A. \& Morrone, O. 2012. Phylogenetic studies in Axonopus (Poaceae, Panicoideae, Paniceae) and related genera: morphology and nmolecular (nuclear and plastid) combined analyses. Systematic Botany 37: 671-676.

Lourteig, A. 1952. Mayacaceae. Notulae Systematicae 14: 234-248.

Louzada, R. 2012. Revisão taxonômica e filogenia de Orthophytum Beer (Bromeliaceae, Bromelioideae). PhD Thesis. Universidade de São Paulo, São Paulo. 186p.

Louzada, R. \& Versieux, L. 2010. Lapanthus (Bromeliaceae, Bromelioideae): A new genus from the southern Espinhaço Range, Brazil. Systematic Botany 35: 497-503.

Louzada, R. \& Wanderley, M. 2010. Revision of Orthophytum (Bromeliaceae, Bromelioideae): species with sessile inflorescences. Phytotaxa 13: $1-26$.

Louzada, R.; Schulte, K.; Wanderley, M.; Silvestro, D.; Zizka, G.; Barfuss, M. \& Palma-Silva, C. 2014. Molecular phylogeny of the Brazilian endemic genus Orthophytum (Bromelioideae, Bromeliaceae) and its implications on morphological character evolution. Molecular Phylogenetics and Evolution 77: 54-64.

Luiz-Santos, A. \& Wanderley, M. 2012. Flora da Serra do Cipó, Minas Gerais: Bromeliaceae - Bromelioideae. Boletim de Botânica da Universidade de São Paulo 30: 89-108.

Luceño, M. \& Alves, M. 1997. Clave de los géneros de ciperáceas de Brasil y novedades taxonómicas y corologicas en la família. Candollea 52: 185-191.

Luceño, M.; Alves, M. \& Mendes, A. 1999. Catálogo florístico y claves de identificación de las Cyperaceae de los estados de Paraíba y Pernambuco (Nordeste de Brasil). Anales del Jardín Botánico de Madrid 55: 67-100.

Luteyn, J. \& Churchill, S. 2000. Vegetation of the tropical Andes: an overview, In: Lentz, D. (ed.). Imperfect Balance: landscape transformations in the preColumbian Americas. Columbia University Press, New York. Pp. 281-310.
Luther, H. 2012. An alphabetical list of bromeliad binomials. $13^{\text {th }}$ ed. Marie Selby Botanical Gardens \& Bromeliad Society International, Sarasota.

Machado, T. 2012. A flora de Bromeliaceae no Parque Nacional do Caparaó, MG/ES: tratamento taxonômico e influência das variáveis climáticas na composição de espécies no sudeste brasileiro. Master Dissertation. Universidade Federal de Minas Gerais, Belo Horizonte. 140p.

Maguire, B. 1958. Rapateaceae. In: Maguire, B. et al. (cols.). Botany of the Guyana Highlands part 3. Memoirs of the New York Botanical Garden 10: 19-49.

Maguire, B. 1958. Rapateaceae. In: Maguire, B. et al. (cols.). Botany of the Guyana Highlands part 3. Memoirs of the New York Botanical Garden 12: 69-102.

Malme, G. 1913a. Die amerikanischen spezies der gattung Xyris L., untergattung Euxyris (Endlicher). Almqvist \& Wiksell, Stockolm. 32p.

Malme, G. 1913b. Xyris L., Untergattung Nematopus (Seubert): Entwurf einer Gliederung. Almqvist \& Wiksell, Stockolm. 103p.

Mantovani, A.; Venda, A.; Almeida, V.; Costa,, A. \& Forzza, R. 2012. Leaf anatomy of Quesnelia (Bromeliaceae): implications for the systematics of core bromelioids. Plant Systematics and Evolution 298: 787-800.

Martinelli, G. \& Forzza, R. 2006. Pitcairnia L'Hér. (Bromeliaceae): uma nova espécie, P. azouryi Martinelli \& Forzza, e observações sobre $P$. encholirioides L.B.Sm. Revista Brasileira de Botânica 29: 603-607.

Martinelli, G. \& Moraes, M. (orgs.) 2013. Livro Vermelho da Flora do Brasil (Red Book of Brazilian Flora). Jardim Botânico do Rio de Janeiro \& Andrea Jakobson Estúdio, Rio de Janeiro. 1100p.

Martinelli, G.; Vieira, C.; Gonzalez, M.; Leitman, P.; Piratininga, A.; Costa, A. \& Forzza, R. 2008. Bromeliaceae da Mata Atlântica brasileira: lista de espécies, distribuição e conservação. Rodriguesia 59: 209-258.

Mez, C. 1894. Bromeliaceae. In: Martius, C.; Eichler, A. \& Urban, I. (eds.). Flora Brasiliensis. München, Wien, Leipzig. Vol. 3, num. 3, pp. 172-634.

Mez, C. 1896. Bromeliaceae. In: Candolle, A. \& Candolle, A. Monographie Phanerogannarum. G. Masson. Paris. Vol. 9, pp. 1-990.

Michelangeli, F.; Davis, J. \& Stevenson, D. 2003. Phylogenetic relationships among Poaceae and related families as inferred from morphology, inversions in the plastid genome, and sequence data from the mitochondrial and plastid genomes. American Journal of Botany 90: 93-106.

Monteiro, R. 2009. Estudos anatômicos e filogenéticos em Bromelia L. (Bromeliaceae - Bromelioideae). Master Dissertation. Jardim Botânico do Rio de Janeiro, Rio de Janeiro. 84p. 
Monteiro, R. 2014. Rapateaceae. In: Lista de Espécies da Flora do Brasil. Jardim Botânico do Rio de Janeiro. Available at $<$ http://floradobrasil.jbrj.gov. br/>. Access on 30 October 2014.

Monteiro, R. \& Forzza, R. 2008. A família Bromeliaceae no Parque Estadual do Ibitipoca, Minas Gerais, Brasil. Boletim de Botânica da Universidade de São Paulo 26: 7-33.

Monteiro, R.; Forzza, R. \& Mantovani, A. 2010. Leaf structure of Bromelia and its significance for the evolution of Bromelioideae (Bromeliaceae). Plant Systematic and Evolution 293: 53-64.

Morrone, O.; Aagesen, L.; Scataglini, M.; Salariato, D.; Denham, S.; Chemisquy, M.; Sede, S.; Giussani, L.; Kellogg, E. \& Zuloaga, F. 2012. Phylogeny of the Paniceae (Poaceae: Panicoideae): integrating plastid DNA sequences and morphology into a new classification. Cladistics 28: 333-356.

Morrone, O.; Denham, S.; Aliscioni, S. \& Zuloaga, F. 2008. Parodiophyllochloa, a new genus segregated from Panicum (Paniceae, Poaceae) based on morphological and molecular data. Systematic Botany 33: 66-76.

Morrone, O.; Scataglini, M. \& Zuloaga, F. 2007. Cyphonanthus, a new genus segregated from Panicum (Poaceae: Panicoideae: Paniceae) based on morphological, anatomical and molecular data. Taxon 56: 521-532.

Morrone, O. \& Zuloaga, F. 2009. Keratochlaena, el nombre correcto para Sclerochlamys (Poaceae, Paniceae). Darwiniana, nueva serie 47: 231-231.

Mota, N. 2014. Filogenia e diversidade de Xyridaceae Neotropicais, com ênfase no gênero Xyris. PhD Thesis. Universidade Federal de Minas Gerais, Belo Horizonte. 174p.

Mota, N. \& Wanderley, M. 2013. Xyris riopretensis (Xyridaceae): a new species from Minas Gerais, Brazil. Rodriguesia 64: 555-560.

Mota, N. \& Wanderley, M. 2014. Three new species of Xyris (Xyridaceae) from Diamantina Plateau in Brazil, Minas Gerais. Brittonia 66: 42-50.

Moura, R. 2011. Revisão taxonônica do grupo Vriesea platynema Gaudich. (Bromeliaceae). PhD Thesis. Universidade Federal do Rio de Janeiro, Rio de Janeiro. 192p.

Moura, R. \& Costa, A. 2014. Taxonomic notes on Vriesea Sect. Xiphion (Bromeliaceae) with descriptions of three new species. Systematic Botany 39: 791-803.

Moura, R.; Costa, A. \& Araújo, D. 2007. A família Bromeliaceae nas restingas fluminenses: florística e fitogeografia. Arquivos do Museu Nacional 65: 139-168.

Muasya, A.; Simpson, D.; Verboom, G.; Goetghebeur, P.; Naczi, R.; Chase, M. \& Smets, E. 2009a. Phylogeny of Cyperaceae based on DNA sequence data: current progress and future prospects. Botanical Review 75: 2-21.
Muasya, A.; Vrijdaghs, A.; Simpson, D.; Chase, M.; Goetghebeur, P. \& Smets, E. 2009b. What is a genus in Cypereae: phylogeny, character homology assessment and generic circumscription in Cypereae. Botanical Review 75: 52-66.

Navara, L. 1996. Juncaceae. In: Zuloaga, F. \& Morrone, O. (eds.). Catálogo de Plantas vasculares da Argentina. Monographs in Systematic Botany, Missouri Botanical Garden 60: 218-226.

Oliveira, A. \& Bove, C. 2011. Two new species of Eriocaulon from the Tocantins-Araguaia River basin, Brazil. Systematic Botany 36: 605-609.

Oliveira, R.; Clark, L.; Schnadelbach, A.; Monteiro, S.; Borba, E.; Longhi-Wagner, H. \& van den Berg, C. 2014. A molecular phylogeny of Raddia and its allies within the tribe Olyreae (Poaceae, Bambusoideae) based on noncoding plastid and nuclear spacers. Molecular Phylogenetics and Evolution 78: 105-117.

Palma-Silva, C.; Wendt, T.; Pinheiro, F.; Barbará, T.; Fay, M.; Cozzolino, S. \& Lexer, C. 2011. Sympatric bromeliad species (Pitcairnia spp.) facilitate tests of mechanisms involved in species cohesion and reproductive isolation in Neotropical inselbergs. Molecular Ecology 20: 3185-3201.

Parra, L. \& Giulietti, A. 1997. Nomenclatural and taxonomic changes in Brazilian Syngonanthus (Eriocaulaceae). Willdenowia 27: 227-233.

Peters, J. 2009. Revision of the genus Fosterella L.B.Sm. (Bromeliaceae). PhD Thesis. University of Kassel, Kassel. 202p.

Peters, J.; Vásquez, R.; Osinaga, A.; Leme, E.; Weising, K. \& Ibisch, P. 2008. Towards a taxonomic revision of the genus Fosterella (Bromeliaceae). Selbyana, 29: 182-194.

Peterson, P.; Romaschenko, K. \& Herrera Arrieta, Y. 2014. A molecular phylogeny and classification of the Cteniinae, Farragininae, Gouiniinae, Gymnopogoninae, Perotidinae, and Trichoneurinae (Poaceae: Chloridoideae: Cynodonteae). Taxon 63: 275-286.

Peterson, P.; Romaschenko, K. \& Johnson, G. 2010. A classification of the Chloridoideae (Poaceae) based on multi-gene phylogenetic trees. Molecular Phylogenetics and Evolution 55: 580-598.

Peterson, P.; Romaschenko, K.; Snow, N. \& Johnson, G. 2012. A molecular phylogeny and classification of Leptochloa (Poaceae: Chloridoideae: Chlorideae) s.1. and related genera. Annals of Botany 109: 1317-1329.

Peterson, P.; Soreng, R.; Davidse, G.; Filgueiras, T.; Zuloaga, F. \& Judziewicz, E. 2001. Catalogue of New World Grasses (Poaceae): II. Subfamily Chloridoideae. Contributions from the United States National Herbarium 41: 1-255.

Pilger, R. 1930. Rapateaceae. In: Engler, A. Die natürlichen Pflanzenfamilien. Vol. 15a. W. Engelmann, Leipzig. Pp. 59-65. 
Raechal, L. \& Strong, M. 2007. Typhaceae. 2007. In: Kunk, V.; Hallowell, T.; Berry, P.; Kelloff, C. \& Alexander, S. Checklist of the plants of the Guayana Shield. Washington Museum of Natural History, Washington. 178p.

Ramírez, I. 1996. Systematics, Phylogeny and Chromosome number evolution in Cryptanthus (Bromeliaceae). Ph.D. Thesis. University of Missouri, St.Louis. 268p.

Ramírez, I. 2000. Neoregelia_subgenus Hylaeaicum. In: Bromeliaceae: Profile of an adaptive radiation. Cambrigde University Press, Cambridge. 590p.

Reid, C.; Carter, R. \& Urbatsch, L. 2014. Phylogenetic insights into New World Cyperus (Cyperaceae) using nuclear ITS sequences. Brittonia 66: 292-305.

Ribeiro, M.; Metzger, J.; Martensen, A.; Ponzoni, F. \& Hirota, M. 2009. The Brazilian Atlantic Forest: How much is left, and how is the remaining forest distributed? Implications for conservation. Biological Conservation 142: 1141-1153.

Ribeiro, J. \& Walter, B. 1998. Fitofisionomias do bioma cerrado. In: Sano, S. \& Almeida, S. Cerrado: ambiente e flora. IBAMA, Planaltina. Pp. 89-166.

Riina, R. \& Berry, P. 2005. Thurniaceae. In: Berry, P.; Yatskievych, K. \& Holst, B. (eds.). Flora of the Guayana Venezuelana. Vol. 9. Missouri Botanical Garden, Saint Louis. Pp. 330-332.

Romaschenko, K.; Peterson, P.; Soreng, R.; Garcia-Jacas, N.; Futorna, O. \& Susanna, A. 2012. Systematics and evolution of the needle grasses (Pooideae: Stipeae) based on analysis of multiple chloroplast loci, ITS, and lemma micromorphology. Taxon 61: 18-44.

Romaschenko, K.; Peterson, P.; Soreng, R.; GarciaJacas, N. \& Susanna, A. 2010. Phylogenetics of Stipeae (Poaceae: Pooideae) Based on Plastid and Nuclear DNA sequences. In: Diversity, Phylogeny, and Evolution in the Monocotyledons, Aarhus University Press, Aarhus. Pp. 511-538.

Ruhland, W. 1903. Eriocaulaceae In: Engler, A. (ed.). Das Pflanzenreich 4 (heft 3). Wilhelm Engelmann, Leipzig. Pp. 1-294.

Ruiz-Sanchez, E.; Sosa, V. \& Mejía-Saules, M. 2011. Molecular phylogenetics of the Mesoamerican bamboo Olmeca (Poaceae, Bambuseae): Implications for taxonomy. Taxon 60: 89-98.

Ruiz-Sanchez, E.; Sosa, V.; Mejía-Saules, M.; Londoño, X. \& Clark, L. 2008. Phylogenetics of Otatea inferred from morphology and chloroplast DNA sequence data, and recircumscription of Guaduinae (Poaceae: Bambusoideae). Systematic Botany 33: 277-283.

Salariato, D.; Giussani, L.; Morrone, O. \& Zuloaga, F. 2009. Rupichloa, a new genus segregated from Urochloa (Poaceae) base on morphological and molecular data. Taxon 58: 381-391.

Sano, P. 2004. Actinocephalus (Körn.) Sano (Paepalanthus sect. Actinocephalus), a new genus of Eriocaulaceae, and other taxonomic and nomenclatural changes involving Paepalanthus Mart. Taxon 53: 99-107.

Santos-Silva, F.; Saraiva, D.; Monteiro, R.; Pita, P.; Mantovani, A. \& Forzza, R. 2013. Invasion of the South American dry diagonal: What can the leaf anatomy of Pitcairnioideae (Bromeliaceae) tell us about it? Flora 208: 508-521.

Saraiva, D. 2013. Filogenia morfológica de Pitcairnia L'Hér. (Bromeliaceae-Pitcairnioideae). Master Dissertation. Jardim Botânico do Rio de Janeiro, Rio de Janeiro. 79p.

Saraiva, D. \& Forzza, R. 2012. Pitcairnia frequens (Bromeliaceae), a neglected new species from Morro dos Seis Lagos, Amazonas, Brazil. Phytotaxa 69: 57-63.

Sass, C. \& Specht, C. 2010. Phylogenetic estimation of the core Bromelioids with an emphasis on the genus Aechmea (Bromeliaceae). Molecular Phylogenetics and Evolution 55: 559-571.

Scataglini, M. \& Zuloaga, F. 2013. Morronea, A New Genus Segregated from Panicum (Paniceae, Poaceae) Based on Morphological and Molecular Data. Systematic Botany 38: 1076-1086.

Schneider, J.; Döring, E.; Hilu, K. \& Röser, M. 2009. Phylogenetic structure of the grass subfamily Pooideae base on comparison of plastid matK gene-3 'trnK exon and nuclear ITS sequences. Taxon 58: 405-424.

Schulte, K.; Barfuss, M. \& Zizka, G. 2009. Phylogeny of Bromelioideae (Bromeliaceae) inferred from nuclear and plastid DNA loci reveals the evolution of the tank habit within the subfamily. Molecular Phylogenetics and Evolution 51: 327-339.

Schulte, K.; Silvestro, D.; Kiehlmann, E.; Vesely, S.; Novoa, P. \& Zizka, G. 2010. Detection of recent hybridization between sympatric Chilean Puya species (Bromeliaceae) using AFLP markers and reconstruction of complex relationships. Molecular Phylogenetics and Evolution 57: 1105-1119.

Schutz N. 2011. Systematics, morphology and taxonomy of the genus Deuterocohnia L.B.Sm. Bromeliaceae. $\mathrm{PhD}$ Thesis. University of Kassel, Kassel. 292p.

Sede, S.; Morrone, O.; Giussani, L. \& Zuloaga, F. 2008. Phylogenetic studies in the Paniceae (Poaceae): a realignment of sect. Lorea of Panicum. Systematic Botany 33: 284-300.

Sede, S.; Morrone, O.; Aliscioni, S.; Giussani, L. \& Zuloaga, F. 2009a. Oncorhachis and Sclerochlamys, two new segregated genera from Streptostachys (Poaceae, Panicoideae, Paniceae): a revision based on molecular, morphological and anatomical characters. Taxon 58: 365-374.

Sede, S.; Zuloaga, F. \& Morrone, O. 2009b. Phylogenetic studies in the Paniceae (Poaceae-Panicoideae): Ocellochloa, a new genus from the New World. Systematic Botany 34: 684-692. 
Seubert, M. 1855. Xyridaceae In: Martius, C. \& Eichler, A. Flora brasiliensis. München, Wien, Leipzig. Vol. 3, pp. 209-224.

Silva, B. 2014. Revisão taxonômica do complexo Vriesea incurvata Gaudich. (Bromeliaceae). Master Dissertation. Universidade Federal do Rio de Janeiro, Rio de Janeiro. 79p.

Silva, G. \& Wanderley, M. 2013. The family Xyridaceae in the municipality of Mucugê, Bahia State, Brazil. Hoehnea 40: 51-76.

Simpson, D. 1995a. Cyperaceae. In: Stannard, B.L. (ed.). Flora of Pico das Almas - Chapada Diamantina, Bahia - Brasil. Kew Gardens, London. Pp. 661-682.

Simpson, D. 1995b. Relationships with Cyperales. In: Rudall, P.; Cribb, P.; Cutler, D. \& Humphries, C. (eds.). Monocotyledons: systematics and evolution. Vol. 2. Kew Gardens, London. P. 497-509.

Siqueira-Filho, J. \& Leme, E. 2006. Fragmentos de Mata Atlântica do Nordeste: Biodiversidade, Conservação e suas Bromélias. Andrea Jakobson Estúdio Editorial, Rio de Janeiro. 416 p.

Smith, L. \& Downs, R. 1974. Pitcairnioideae (Bromeliaceae). Flora Neotropica Monograph 14: 1-658.

Smith, L. \& Downs, R. 1977. Tillandsioideae (Bromeliaceae). Flora Neotropica Monograph 14: 663-1492.

Smith, L. \& Downs, R. 1979. Bromelioideae(Bromeliaceae). Flora Neotropica Monograph 14: 1493-2142.

Soreng, R.; Bull, R. \& Gillespie, L. 2010. Phylogeny and reticulation in Poa based on plastid trnTLF and nrITS sequences with attention to diploids. In: Diversity, Phylogeny, and Evolution in the Monocotyledons. Aarhus University Press, Aarhus. Pp. 619-644.

Soreng, R.; Davidse, G.; Peterson, P.; Zuloaga, F.; Judziewicz, E.; Filgueiras, T.; Morrone, O. \& Romaschenko, K. 2014. A World-wide Phylogenetic Classification of Poaceae (Gramineae): căo (草), capim, çayır, çimen, darbha, ghaas, ghas, gish, gramas, graminius, gräser, grasses, gyokh, he-ben-ke, hullu, kasa, kusa, nyasi, pastos, pillu, etc. Available at $<$ http://www.tropicos.org/projectwebportal.aspx?pag ename $=$ ClassificationNWG\&projectid $=10>$. Access on 10 December 2014.

Soreng, R.; Peterson, P.; Davidse, G.; Judziewicz, E.; Zuloaga, F.; Filgueiras, T. \& Morrone, O. 2003. Catalogue of New World Grasses (Poaceae): IV. Subfamily Pooideae. Contributions from the United States National Herbarium 48: 1-730.

Sousa, B. 2011. Revisão taxonômica do complexo Tillandsia sterptocarpa (Tillandsioideae, Bromeliaceae). Master Dissertation. Universidade Federal de Viçosa, Viçosa. 72p.

Sousa, G. 2004. Revisão taxonômica de Aechmea Ruiz \& Pavon subgen. Chevaliera (Gaudich. ex Beer) Baker Bromelioideae - Bromeliaceae. PhD Thesis. Universidade de São Paulo, São Paulo. 181p.
Sousa, L. \& Wendt, T. 2008. Taxonomy and conservation of the genus Lymania (Bromeliaceae) in the southern Bahian Atlantic Forest of Brazil. Botanical Journal of the Linnean Society 157: 47-66.

Sousa, L.; Wendt, T.; Brown, K.; Tuthill, E. \& Evans, M. 2007. Monophyly and phylogenetic relationships in Lymania (Bromeliaceae: Bromelioideae) based on morphology and chloroplast DNA sequences. Systematic Botany 32: 264-270.

Strong, M. \& Acevedo-Rodriguez, P. 2005. Cyperaceae. In: Acevedo-Rodriguez, P. \& Strong, M. (eds.). Monocotyledons and Gimnosperms from Puerto Rico and the Virgin Islands. Smithsonian Contributions to Botany 52: 1-415.

Strong, M. \& Acevedo-Rodriguez, P. 2012. Cyperacaeae. In: Acevedo-Rodriguez, P. \& Strong, M. (eds.). Catalogue of seed plants of West Indies. Smithsonian Contributions to Botany 98: 257-300.

Stützel, T. 1998. Eriocaulaceae. In: Kubitzki, K.; Huber, H.; Rudall, P.; Stevens, P. \& Stützel, T. (eds.). Vascular flowering plants. Vol. 4. Springer, Berlin. Pp. 197-207.

Stevens, P. (2001 onwards). Angiosperm Phylogeny Website. Version 12, July 2012. Available at $<$ http:// www.mobot.org/MOBOT/research/APweb/>. Access on 20 September 2014.

Stevenson, D. 1998. Mayacaceae. In: Kubitzki, K.; Huber, H.; Rudall, P.; Stevens, P. \& Stützel, T. (eds.). Vascular flowering plants. Vol. 4. Springer, Berlin. Pp. 294-296.

Stevenson, D. 2004. Rapateaceae. In: Smith, N.; Mori, S.; Henderson, A.; Stevenson, D. \& Heald, S. (eds.). Flowering plants of the neotropics. Princeton University Press, Princeton. Pp. 485-489.

Stevenson, D. 2004. Thurniaceae. In: Smith, N.; Mori, S.; Henderson, A.; Stevenson, D. \& Heald, S. (eds.). Flowering plants of the neotropics. Princeton University Press, Princeton. Pp. 485-486.

Stevenson, D. 2004. Typhaceae. In: Smith, N.; Mori, S.; Henderson, A.; Stevenson, D. \& Heald, S. (eds.). 2004. Flowering plants of the neotropics. Princeton University Press, Princeton. Pp. 487-489.

Stevenson, D.; Colella, M. \& Boom, B. 1998. Rapateaceae. In: Kubitzki, K.; Huber, H.; Rudall, P.; Stevens, P. \& Stützel, T. (eds.). The Families and Genera of Vascular Plants. Vol. 4. Springer-Verlag, Berlin. Pp. 415-424.

Tardivo, R. 2002. Revisão taxonômica de Tillandsia L. subgênero Anoplophytum (Beer) Baker (Bromeliaceae). PhD Thesis. Universidade de São Paulo, São Paulo. 194p.

Terry, R.; Brown, G. \& Olmstead, R. 1997. Examination of subfamilial phylogeny in Bromeliaceae using comparative sequencing of the plastid locus ndhF. American Journal of Botany 84: 664-670.

Thomas, W., Araújo, A.C. \& Alves, M. 2009. A Preliminary molecular phylogeny of the 
Rhynchosporeae (Cyperaceae). Botanical Review 75: 22-29.

Thomas, W. \& Barbosa, M. 2008. Natural vegetation types in the Atlantic Coastal Forest of Northeastern Brazil. Memoirs of the New York Botanical Garden 100: 6-20.

Tissot-Squalli, M. 1997a. Monographische Bearbeitung von Paepalanthus subgenus Platycaulon. J. Cramer, Berlin. Pp. 1-242.

Tissot-Squalli, M. 1997b. Nomenklatorische Überblick der Untergattung Platycaulon (Paepalanthus) Eriocaulaceae. Feddes Repertorium 108: 381-385.

Tissot-Squalli, M. 1997c. Fünf neue Arten und zwei neue Varietäten der Untergatung Platycaulon (Paepalanthus) - Eriocaulaceae. Feddes Repertorium 108: 361-380.

Trovó, M.\& Costa F. 2009. Actinocephalus koernickeanus, a new species of Eriocaulaceae from Minas Gerais, Brazil. Novon 19: 412-415.

Trovó, M. \& Sano P. 2009. Paepalanthus bonsai, a new species of Eriocaulaceae from Minas Gerais, Brazil. Novon 19: 256-258.

Trovó, M. \& Sano P. 2010a. Nomenclatural and taxonomic changes in Paepalanthus (Eriocaulaceae), from Minas Gerais and São Paulo, Brazil. Kew Bulletin 62: 275-278.

Trovó, M. \& Sano P. 2010b. Actinocephalus verae, a new species of Eriocaulaceae from the Brazilian campos rupestres, Brazil. Brittonia 61: 35-38.

Trovó, M. \& Sano, P. 2011. Five new and narrowly distributed Species of Paepalanthus Section Diphyomene (Eriocaulaceae) from Central Brazil. Systematic Botany 36: 610-620.

Trovó, M. \& Sano, P. 2014. Paepalanthus conjunctus, a new species of Paepalanthus sect. Diphyomene (Eriocaulaceae) from Central Brazil. Phytotaxa178: 53-56.

Trovó, M. \& Stützel, T. 2013. On the morphological position of Paepalanthus subgenus Psilandra (Eriocaulaceae). Plant Systematics and Evolution 299: 115-121.

Trovó, M.; Echternacht, L. \& Sano P. 2011. Paepalanthus hirtellus, a new species of Paepalanthus subsection Actinocephaloides (Eriocaulaceae) from Minas Gerais, Brazil. Phytotaxa 15: 26-32.

Trovó, M.; Echternacht, L. \& Sano, P. 2012 a. Paepalanthus sphaeroides, a new species of Eriocaulaceae from the Atlantic Forest, Brazil. Blumea 57: 105-108.

Trovó, M.; Costa, F. \& Echternacht, L. 2012b. Actinocephalus pachyphyllus: re-establishment, redefinition, and a new combination in Eriocaulaceae from Brazil. Kew Bulletin 67: 25-31.

Trovó, M.; Andrade, M.; Sano, P.; Ribeiro, P. \& van den Berg, C. 2013. Molecular phylogenetics and biogeography of Neotropical Paepalanthoideae with emphasis on Brazilian Paepalanthus (Eriocaulaceae). Botanical Journal of the Linnean Society 171: 225-243.

Trovó, M.; Echternacht, L.; Costa, F.; Watanabe, M. \& Sano, P. 2014. Nomenclatural and taxonomic novelties in Eriocaulaceae from the states of Rio de Janeiro and Santa Catarina, Brazil. Phytotaxa162: 217-222.

Tyrrell, C.; Santos-Gonçalves, A.; Clark, L. \& Londoño, X. 2012. Molecular phylogeny of the arthrostylidioid bamboos (Poaceae: Bambusoideae: Bambuseae: Arthrostylidiinae) and new genus Didymogonyx. Molecular Phylogenetics and Evolution 65: 136148.

Uribbe, F. 2014. Revisão taxonômica do complexo Vriesea procera (Tillandsioideae, Bromeliaceae). Master Dissertation. Universidade Federal do Rio de Janeiro, Rio de Janeiro. 85p.

Vargas, C. Typhaceae. 2007. In: Kunk, V.; Hallowell, T.; Berry, P.; Kelloff, C. \& Alexander, S. (eds.). Checklist of the plants of the Guiana Shield. Washington Museum of Natural History, Washington. Pp. 111-112.

Veloso, H.; Rangel Fo., A. \& Lima, J. 1991. Classificação da vegetação brasileira, adaptada a um sistema universal. IBGE, Rio de Janeiro. 124p.

Venda, A. 2012. Filogenia do gênero Neoregelia L.B.Sm. (Bromelioideae -Bromeliaceae). Master Dissertation. Jardim Botânico do Rio de Janeiro, Rio de Janeiro. 50p.

Versieux L. 2009. Sistemática, filogenia e morfologia de Alcantarea (Bromeliaceae). PhD Thesis. Universidade de São Paulo, São Paulo. 252p.

Versieux, L. \& Wendt, T. 2007. Bromeliaceae diversity and conservation in Minas Gerais state, Brazil. Biodiversity and Conservation 16: 2989-3009.

Versieux, L.; Wendt, T.; Louzada, R. \& Wanderely, M. 2008. Bromeliaceae da Cadeia do Espinhaço. Megadiversidade 4: 98-110.

Versieux, L.; Louzada, R.; Viana, P.; Mota, N. \& Wanderely, M. 2010. An illustrated checklist of Bromeliaceae from Parque Estadual do Rio Preto, Minas Gerais, Brazil, with notes on phytogeography and one new species of Cryptanthus. Phytotaxa 10: 1-16.

Versieux, L.; Barbará, T.; Wanderley, M.; Calvente, A.; Fay, M. \& Lexer, C. 2012. Molecular phylogenetics of the brazilian giant bromeliads (Alcantarea, Bromeliaceae): Implications for morphological evolution and biogeography. Molecular Phylogenetics and Evolution 64: 177-89.

Viana, P. \& Filgueiras, T. 2008. Inventário e distribuição geográfica das gramíneas (Poaceae) na Cadeia do Espinhaço, Brasil. Megadiversidade 4: 71-88.

Viana, P.; Filgueiras, T. \& Clark, L. 2013. Cambajuva (Poaceae: Bambusoideae: Bambuseae: 
Arthrostylidiinae), a New Woody Bamboo Genus from Southern Brazil. Systematic Botany 38: 97-103.

Wanderley, M. 2010. Cinco novas espécies de Xyris (Xyridaceae) da Serra do Cipó, Minas Gerais, Brasil. Rodriguésia 61: 83-94.

Wanderley, M. 2011. Flora da Serra do Cipó, Minas Gerais: Xyridaceae. Boletim de Botânica da Universidade de São Paulo 29: 69-134.

Wanderley, M. \& Forzza, R. 2003. Flora de Grão-Mogol, Minas Gerais: Bromeliaceae. Boletim de Botânica 21: 131-139.

Wanderley, M. \& Martins, S. 2007. Bromeliaceae. In: Melhem, T.S.; Wanderley, M.; Martins, S.; JungMendeçolli, S.; Shepherd, G.; Kirizawa, M. Flora Fanerogâmica do Estado de São Paulo. Instituto de Botânica, São Paulo. Vol 5, pp. 39-161.

Wanderley, M.; Silva, G.; Guedes, J. \& Mota. N. 2014. Xyridaceae. In: Lista de espécies da flora do Brasil, Rio de Janeiro. Available at $<$ http://floradobrasil. jbrj.gov.br/2014/>. Access on 10 October 2014.

Wanderley, M. \& Silva, M. 2009. Flora de Grão-Mogol, Minas Gerais: Xyridaceae. Boletim de Botânica da Universidade de São Paulo 27: 137-147.
Wanderley, M.; Sousa, G. \& Alves, M. 2014. Dyckia tubifilamentosa (Pitcairnioideae-Bromeliaceae): a new species form Northeastern Brazil. Hoehnea 41: 315-319.

Zanella, M.; Bruxel, M.; Paggi, G.; Goetze, M.; Buttow, M.; Cidade, F. \& Bered, F. 2011. Genetic structure and phenotypic variation in wild populations of the medicinal tetraploid species Bromelia antiacantha (Bromeliaceae). American Journal of Botany 98: 1511-1519.

Zuloaga, F.; Morrone, O.; Davidse, G.; Filgueiras, T.; Peterson, P.; Soreng, R. \& Judziewicz, E. 2003. Catalogue of New World Grasses (Poaceae): III. Subfamilies Panicoideae, Aristidoideae, Arundinoideae, and Danthonioideae. Contributions from the United States National Herbarium 46: 1-662.

Zuloaga, F.; Morrone, O. \& Scataglini, M. 2011. Monograph of Trichanthecium (Poaceae, Paniceae). Systematic botany monographs 94: 1-101.

Zuloaga, F.; Scataglini, M. \& Morrone, O. 2010. A phylogenetic evaluation of Panicum sects. Agrostoidea, Megista, Prionita and Tenera (Panicoideae, Poaceae): Two new genera, Stephostachys and Sorengia. Taxon 59: 1535-1546. 